\title{
Norcantharidin: A potential antiangiogenic agent for gallbladder cancers in vitro and in vivo
}

\author{
JING-TAO ZHANG $^{1}$, YUE-ZU FAN ${ }^{1}$, CHUN-QIU CHEN $^{2}$, ZHE-MING ZHAO $^{1}$ and WEI SUN ${ }^{1}$ \\ ${ }^{1}$ Department of Surgery, Tongji Hospital, Tongji University School of Medicine; ${ }^{2}$ Department of Surgery, \\ Shanghai Tenth People's Hospital, Tongji University, Shanghai, P.R. China
}

Received October 11, 2011; Accepted December 2, 2011

DOI: $10.3892 /$ ijo.2011.1314

\begin{abstract}
Our objective was to explore the antiangiogenic activity of norcantharidin (NCTD) as an angiogenic inhibitor for gallbladder cancers. In vitro and in vivo experiments to determine the effects of NCTD on HUVECs, chicken CAM capillaries and gallbladder cancer xenograft angiogenesis in nude mice were respectively done. The MTT method was used to assay the cytotoxicity of NCTD on HUVECs. Immunofluorescence was used to evaluate HUVEC apoptosis. The scraping line method, matrigel invasion assay and tube formation assay were used to detect the migration, invasion and tube formation of HUVECs. A digital camera was used to observe chicken CAM capillaries. Experiments with NCTD in a xenograft model were used to observe the effect of NCTD on xenograft growth and survival of mice with xenografts. $\mathrm{CD}_{34}$ immunohistochemistry, flow cytometry and micro-MRA were used, respectively, to determine MVD, cell apoptosis and hemodynamic analysis of the xenografts. Immunohistochemistry and RT-PCR were used, respectively, to detect the expression of VEGF, Ang-2, TSP, TIMP-2 proteins/mRNAs of the xenografts. The xenograft MVD associated with tumor volume, the PCNA/apoptosis ratio and related-protein expression was evaluated simultaneously. We found that NCTD effectively inhibited the proliferation, migration, invasion and capillary-like tube formation of HUVECs in vitro; it reduced angiogenesis and directly destroyed the formed CAM capillaries in vivo. In the experiments in mice, NCTD not only inhibited significantly xenograft proliferation and growth, prolonged survival time of mice with xenografts, decreased the xenograft MVD and vascular perfusion, but also, similarly to ES, decreased significantly the expression of VEGF or Ang-2 protein/mRNA, increased the expression of TSP or TIMP-2 protein/mRNA. Moreover, the xenograft MVD was positively related with tumor volume, PCNA/apoptosis ratio, and VEGF or Ang-2 expression, respectively (all $\mathrm{P}<0.05$ ), but
\end{abstract}

Correspondence to: Professor Yue-Zu Fan, Department of Surgery, Tongji Hospital, Tongji University School of Medicine, 389 Xincun Road, Shanghai 200065, P.R. China

E-mail: fanyuezu_shtj@yahoo.com.cn

Key words: norcantharidin, gallbladder neoplasm, tumor angiogenesis, antiangiogenic therapy, angiogenic inhibitor negatively correlated with TSP or TIMP-2 expression (both $\mathrm{P}<0.05$ ). These data showed that NCTD could serve as a potential antiangiogenic agent for gallbladder cancers.

\section{Introduction}

The growth and metastasis of tumor depends on the growth of blood vessels and the effective microcirculation (blood supply). Angiogenesis is part of the complicated process of tumor growth and metastasis, by which new blood vessels are created from pre-existing capillaries or vessels. Without angiogenesis, a small focus of tumor cells because of lack of effective microcirculation cannot grow at a secondary site (1-3). The level of angiogenic activity in various tumors has been shown to be a determinant of tumor progression. Among the known angiogenic growth factors and cytokines, vascular endothelial growth factor (VEGF) and its corresponding receptors $(4,5)$, angiopoietin (Ang) $(6,7)$, thrombospondin (TSP) $(8,9)$ and tissue inhibitor of metalloproteinase (TIMP) families play a paramount and indispensable role in regulating the multiple facets of the angiogenic processes $(10,11)$. As angiogenesis plays a central role in tumor growth, progression, invasion and metastasis, inhibition of angiogenesis provides a potential strategy for tumor treatment (12-14). Researchers are currently seeking to develop new angiogenic inhibitors from cleaved proteins, monoclonal antibodies, synthesized small molecules and natural products $(15,16)$. Many angiogenesis inhibitors such as bevacizumab (Avastin, a VEGF inhibitor), sorafenib, erlotinib, sunitinib, angiostatin, endostatin (ES), thrombospondin-1 (TSP-1), celastrol, TNP-470, and SU-5416 have been reported to exhibit antitumor and antiangiogenic activities (16-23). However, recent studies have suggested that the benefits of antiangiogenic therapy have far been rather modest, also, sole blockage of angiogenesis may not be effective $(24,25)$. So, it may be valuable to develop more effective ways to combine antiangiogenic drugs with established chemotherapies, or seek molecules that simultaneously confer both antiangiogenic and antitumor activities (26-29).

Gallbladder carcinoma is the most common malignancy of the biliary tract, the fifth or sixth common malignant neoplasm of the digestive tract and the leading cause of cancer-related deaths in West countries and China (30-33). Because gallbladder cancer is late diagnosis, high aggressive, much angiogenic and poor prognostic malignancy, surgical resection and adjuvant therapies such as chemotherapy and radiotherapy for the disease 
are disappointing (34-39). Clearly, new therapeutic agents are also needed to treat gallbladder cancer in vivo. Evidence has shown that traditional Chinese medicines contain anticancer ingredient. Norcantharidin (NCTD) is a demethylated form of cantharidin with anti-tumor properties, and is an active ingredient of traditional Chinese medicine-Mylabris (40-42). It is effective in inhibiting the proliferation of several tumor cell lines, including HepG2, K562, HL60, A375-S2, HT29, and GBC-SD cells (43-46). Because of its anti-tumor activity, fewer side effects and leukocytosis, NCTD is reported clinically as an anti-tumor drug against hepatoma, esophageal and gastric carcinoma, and leukopenia in China (40-42). We have reported that NCTD has antitumor activity against gallbladder carcinomas in vitro and in vivo $(46,47)$. However the exact mechanism responsible for the NCTD anti-tumor is not thoroughly elucidated. In this study, we further studied the antiangiogenic activity of NCTD as an angiogenic inhibitor and its possible mechanism.

\section{Materials and methods}

Cell lines, cell culture and identifying. Human umbilical vein endothelial cells (HUVECs) were isolated from human umbilical cord veins in neonate (from the Gynecologic Department of Tongji Hospital, Tongji University School of Medicine, Shanghai, China) by collagenase treatment as described by previously (48), and made into single-cell suspensions at concentration of $2 \times 10^{6}$ cells $/ \mathrm{ml}$ of HUVECs. Then, the cells were cultured in glutin-peridium culture-flask in an incubator (Forma series II HEPA Class 100, Thermo Co., USA) under a humidified $95 \%$ and with $5 \%(\mathrm{v} / \mathrm{v})$ mixture of air and $\mathrm{CO}_{2}$ at $37^{\circ} \mathrm{C}$. When the cells became confluent at $80 \%$ plating efficiency, they were stained by $\mathrm{CD}_{34}$ immunocytochemistry of streptavidin-biotin complex (SABC) method. Cells plated on slides were treated with acetoneformaldehyde (1:1), $3 \% \mathrm{H}_{2} \mathrm{O}_{2}$ solution and $10 \%$ goat serum (Wuhan Boster Co., China), were added in order with primary antibody $\left(\mathrm{CD}_{34}\right.$, mouse monoclonal antibody, 1:80, Serotec Co., USA), biotinylated secondary antibody (goat anti-mouse $\mathrm{IgG}$, 1:200, Antibody Diagnostic Inc., USA), SABC reagents and hydrogen-peroxidase-diaminobenzidine (DAB) solution (Wuhan Boster Co., China), respectively. Then, the slices were rinsed in distilled water, dehydrated through alcohol and xylene, mounted coverslip using a permanent mount medium, and observed by an optic microscope (Olympus, Japan). For negative control, the slides were treated with phosphate-buffered saline (PBS) solution in place of primary antibody.

GBC-SD cell lines of human gallbladder carcinoma were from the Shanghai Institute of Biochemistry and Cell Biology (SIBCB, China), were cultured in RPMI-1640 medium (Gibco, USA) supplemented with $10 \%$ bovine calf serum (Hangzhou Sijiqing Biological Co., China) in an incubator (Forma Scientific Co., USA) with $5 \% \mathrm{CO}_{2}$ at $37^{\circ} \mathrm{C}$. When the cells became confluent at $95 \%$ plating efficiency, they were digested with $0.25 \%$ trypsin (Gibco, USA) and observed by inversion microscope (Chongqin Optician, China). Then the cells were retuned to culture at $37^{\circ} \mathrm{C}$ in $5 \% \mathrm{CO}_{2}$ for $24 \mathrm{~h}$, and they were washed twice with Hanks' balanced salt solution (HBSS, Gibco, USA), were used in the experiments.

Proliferation assay in vitro. The cultured HUVEC suspensions were used in acute toxicity test. Maximal $(120 \mu \mathrm{g} / \mathrm{ml})$ or minimal
$(5 \mu \mathrm{g} / \mathrm{ml})$ effective dose was calculated respectively from proexperiments. After HUVECs $\left(2 \times 10^{6}\right.$ cells/well) were cultured in the 96-well plates in endothelial cell growth medium (ECGM) with vascular endothelial growth factor (VEGF, ScienCell Research Laboratories, USA) and the culture medium without VEGF overnight, they were treated without (negative control, normal saline) or with various concentrations of NCTD [experimental groups, the dose diluted at equal ratio with 1:0.8 NCTD/ normal saline; from Jiangsu Kangxi Ltd., China [(Injection solution, $5 \mathrm{mg} / \mathrm{ml})$ ] in fresh culture medium at $37^{\circ} \mathrm{C}$ for $24 \mathrm{~h}$. The tetrazolium-based colorimetric assay (MTT; Sigma) was used to evaluate the inhibitory effect of NCTD on growth of HUVECs in vitro. The concentration of drug giving $50 \%$ inhibition concentration $\left(\mathrm{IC}_{50}\right)$ for the growth of HUVECs was calculated from the formula $\mathrm{IC}_{50}=\mathrm{lg}^{-1}\left[\mathrm{Xm}-\mathrm{I}\left(\sum \mathrm{p}-0.5\right)\right]$.

Apoptosis assay in vitro. On the basis of $\mathrm{IC}_{50}$ of NCTD or endostatin (ES, Molecular Probes Co., USA), HUVECs cultured on the glutin-peridium slides in the 96-well plates with culture medium $\left(2 \times 10^{6}\right.$ cells/well) were treated without (negative control, normal saline) and with the dilutions of NCTD (at dose of $\mathrm{IC}_{50}$ ), ES (at dose of $\mathrm{IC}_{50}$ ) or NCTD+ES (which all were dissolved in normal saline), respectively. Then, the slides were washed with PBS solution, fixed with $4 \%$ formalin, again washed with PBS solution, and stained with fluorescence agent Hoechst 33258 (CH-9470 Buchs, Fluka AG Co., USA) at concentration of $10 \mu \mathrm{g} / \mathrm{ml}$ at $6,12,16,20$ and $24 \mathrm{~h}$. Apoptosis of HUVECs was observed under a fluorescence microscope (Nikon Eclipse TE2000-U, Japan). Ten sample slides in each group were chosen by analysis. More than ten visual fields were observed or $>500$ cells were counted per slide. The apoptotic percent of each group $=$ apoptotic cells/cells in all $\mathrm{x} 100 \%$.

Migration assay in vitro. The cultured HUVECs were inoculated in 4 culture dishes peridiumed with fibronectin $\left(2 \times 10^{6}\right.$ cells $/ \mathrm{ml}$ $\mathrm{x} 100 \mu \mathrm{l} / \mathrm{dish}$ ) in fresh culture medium (ECGM, $100 \mu \mathrm{l} / \mathrm{dish}$ ). When HUVECs were fused into a single layer in dishes, a straight line on the surface of the growing cells was scraped with sterile blades by scraping line method. Then, the cells at side of the line were scraped off completely using a plastic scraper, washed with D-Hanks. The cultures were treated without (negative control, equal ECGM solution) or treated with various concentrations (12.5-50 $\mu \mathrm{g} / \mathrm{ml}$, experimental groups, 4 dishes per concentration) of NCTD in fresh culture medium at $37^{\circ} \mathrm{C}$ in $5 \% \mathrm{CO}_{2}$ for $24 \mathrm{~h}$. Lastly, cell migration distance onto the scraped areas and migrating cells were measured and counted in four independent microscopic visual fields (x100) under an inversion microscope (Nikon TS100, Japan), and expressed as mean number per one field, so as to determine the inhibitory effect of NCTD on proliferation and migration of HUVECs.

Invasion assay in vitro. Living HUVECs were trypsinized with $0.25 \%$ trypsin and washed with fresh culture medium, suspended in the culture medium with $10 \%$ bovine calf serum $\left(2 \times 10^{6}\right.$ cells/ $\mathrm{ml})$. The cell suspension was transferred to the above layer of the matrigel invasion chamber $(0.3 \mathrm{ml} / \mathrm{each}$ chamber $)$, while 0.8 $\mathrm{ml}$ of RPMI-1640 medium with $10 \%$ bovine calf serum was only added to the bottom layer of the matrigel invasion chamber. Then the cells were cultured in $50 \mathrm{ml} / 1 \mathrm{CO}_{2}$ at $37^{\circ} \mathrm{C}$ for $24 \mathrm{~h}$. The cells were treated without (untreated control group) or with 
various concentrations of NCTD (the six-concentration groups, each concentration $\mathrm{x} 6)$ in fresh culture medium $(0.3 \mathrm{ml} / \mathrm{each}$ chamber), were cultured in an incubator with $50 \mathrm{ml} / 1$ at $37^{\circ} \mathrm{C}$ for $72 \mathrm{~h}$. The passing-membrane cells were collected from the above layer of the matrigel invasion chamber, centrifuged $(200 \mathrm{r} / \mathrm{min}$, $10 \mathrm{~min}$ ), dyed by trypan blue dye, and counted in a hemocytometer. Each experiment was performed three times.

Tube formation assay in vitro. Vascular tube formation assay of HUVEC in vitro was performed according to previous description $(14,15)$. Briefly, 96-well plates were coated with matrigel $(0.05 \mathrm{ml})$ and incubated at $37^{\circ} \mathrm{C}$ for $1 \mathrm{~h}$ to promote gelling. HUVEC suspensions $\left(2 \times 10^{6}\right.$ cells/well $)$ were seeded on the matrigel and treated with NCTD solutions at various concentrations $(5-50 \mu \mathrm{g} / \mathrm{ml})$ or ES solution $(20 \mu \mathrm{g} / \mathrm{ml}), 6 /$ each group for 24 h. A phase-contrast microscope (MS5, Leica, Switzerland) was used to record tube formation by HUVECs. Tube formation ability was quantified by counting the total number of cell clusters and branching in five randomly chosen microscopic fields per well under magnification $\mathrm{x} 100$. Results were expressed as the mean percentage of branching over total cell clusters and expressed as a ratio to the control.

Angiogenesis assay of chicken embryo CAM in vivo. The assay of chicken embryo chorioallantoic membrane (CAM) capillaries was performed as described previously $(49,50)$, with some modifications. Briefly, fertilized chicken eggs $(n=120$, from the Chicken Farm of Shanghai Jiaotong University School of Agriculture, China) were incubated in a constant humidified egg incubator (Lyon, CA, USA) with $55 \%$ relative humidity at $37.8^{\circ} \mathrm{C}$ for eight days, and then a small hole was punched into the broad side of the egg and a window was carefully created in the eggshell for developing CAM from the shell. On the basis of the pro-experiment results, CAM experiments in vivo were randomly divided into a negative control (normal saline, $\mathrm{n}=20$ ), 4 groups of NCTD at different concentration $(0.5,1.0,2.5$ and $5.0 \mathrm{mg} / \mathrm{ml} ; 20 /$ each group), and a positive control (ES, $1.0 \mathrm{mg} /$ $\mathrm{ml} ; \mathrm{n}=20)$. Different concentration $(20 \mu \mathrm{l})$ of NCTD or ES were air-dried onto sterile glass coverslips of $\sim 1 \mathrm{~mm}^{2}$ and applied to the CAM surface. The coverslips were placed onto well-vascularized sites of the CAM of the developing chick embryos, and the eggs were returned to the humidified egg incubator for three days. Then, the sites were evaluated and recorded with a digital camera (Canon 5D Mark II, Japan) and a microscopic photography (MS5, Leica, Switzerland). Angiogenesis was quantified by counting the number of blood vessel branch points in each photo. A positive antiangiogenic effect was scored when the microvessels were obviously reduced and destroyed under the coverslips. At least ten viable embryos were tested for each treatment.

Acute toxicity test, xenograft inhibition assay and survival analysis in vivo. All of procedures were performed on the animals according to the official recommendations of Chinese Community Guidelines. Balb/c nu/nu mice (equal numbers of male and female mice, 5-week old, $20 \mathrm{~g})$ and white rats $(\mathrm{n}=66)$ from the Shanghai Laboratory Animal Center (Shanghai, China) were housed in specific pathogen-free condition.

Acute toxicity test: white rats were randomly divided into 6 groups (11 rats/each group). Maximal $(250 \mathrm{mg} / \mathrm{kg}$ ) or minimal $(102.4 \mathrm{mg} / \mathrm{kg})$ lethal dose was calculated from pro-experiments.
NCTD dose among groups was diluted at equal ratio (NCTD: normal saline $=1: 0.8$ ). White rats in 6 groups were injected intraperitoneally with above-mentioned dose of NCTD, respectively. Acute toxic reaction and death in white rats were observed. The concentration of drug giving $50 \%$ of lethal dose $\left(\mathrm{LD}_{50}\right)$ was calculated from the formula $\mathrm{LD}_{50}=\lg ^{-1}\left[\mathrm{Xm}-\mathrm{I}\left(\sum \mathrm{p}-0.5\right)\right]$.

The tumor xenograft model was established by subcutaneous implantation of cultured GBC-SD cells $\left(1.8 \times 10^{7} / \mathrm{ml}\right)$ in $0.2 \mathrm{ml} \mathrm{HBSS}$ into the right axilback of nude mice as described by us previously (47). By 2 weeks a solid tumor was apparent in all mice that received GBC-SD cell injections showing that the xenograft models were constructed successfully. The mice with the xenografts used in the experiments were randomly divided into a control group, receiving intraperitoneal (i.p.) injections of $0.1 \mathrm{ml}$ of normal saline without NCTD twice each week, a NCTD group, a 5-FU group (Shanghai Xudonghaipu Pharmaceutical Co., China), an ES group, a NCTD+5-FU group and a NCTD+ES group (10 mice per group), in which each mouse received i.p. injections of NCTD $(28 \mathrm{mg} / \mathrm{kg})$ or $5-\mathrm{FU}(24$ $\mathrm{mg} / \mathrm{kg})$ or $\mathrm{ES}(30 \mathrm{mg} / \mathrm{kg})$ at a dose of $1 / 5 \mathrm{LD}_{50}$ given in 0.1 $\mathrm{ml}$ of normal saline, or $28 \mathrm{mg} / \mathrm{kg} \mathrm{NCTD}+24 \mathrm{mg} / \mathrm{kg} 5-\mathrm{FU}$, or $28 \mathrm{mg} / \mathrm{kg} \mathrm{NCTD}+30 \mathrm{mg} / \mathrm{kg}$ ES, twice each week for 6 weeks in all. The xenograft size or volume and body weight of each mouse were determined weekly by a single observer. The tumor volume $\left(\mathrm{cm}^{3}\right)$ was measured with vernier caliper $\left(V=1 / 6 \pi a b^{2}\right.$, $a$, long radius; $b$, short radius). Also, tumor growth curve and tumor inhibitory rate of each group, and survival time of NCTD group or control group were respectively evaluated. Tumor inhibitory rate $=($ volume in control group - volume in experimental group)/volume in control group x $100 \%$. The outcome was followed from the date of NCTD injection to the date of death. The median follow-up period for mice was 16 (range 3-30) weeks.

Xenograft MVD assay in vivo. Microvessel density (MVD) was assessed by immunostaining as described previously (51) with modification. Sections were digested with trypsin at room temperature for $30 \mathrm{~min}$, and incubated in order with a blocking agent (LSAB kit, Dako, Denmark) for $1 \mathrm{~h}$, a rabbit anti-human $\mathrm{CD}_{34}$ with a dilution of 1:200 at $4^{\circ} \mathrm{C}$ overnight, Link reagent (LSAB kit, Dako) for $1 \mathrm{~h}$ followed by streptavidin for another $1 \mathrm{~h}$, and DAB to visualize the microvessels. Then, the sections were rinsed in distilled water, dehydrated through alcohol and xylene, mounted coverslip using a permanent mount medium, and observed by an optic microscope (Olympus, Japan). For negative control, the sections were treated with PBS in place of primary antibody. The results of MVD were expressed as the average number of microvessels per field (x400) for 10 slices (27).

Xenograft vascular perfusion assay in vivo. Xenograft vascular perfusion assay was taken out using the method as described by us previously (52), i.e., dynamic micro-magnetic resonance angiography (micro-MRA) with intravascular contrast agent using a $1.5 \mathrm{~T}$ MRI from Marconic Co., USA) for the xenografts of nude mice (7-week old) in vivo. Micro-MRA was performed to analyze hemodynamics in the angiogenesis (marginal tumor) regions. The images were acquired before injection of the contrast agents and 2, 5 and 15 min after injection. Three regions of interest (ROI) in the marginal area of the 
xenograft tumors and counted time-coursed pixel numbers per $\mathrm{mm}^{3}$ were analyzed. All of the data $(\mathrm{n}=6)$ were obtained directly from the MRA analyzer and were expressed as the mean $\pm \mathrm{SD}$.

Flow cytometry in vivo. Ten samples of the fresh xenografts in each group were gathered, washed with PBS solution, incised into tissue shivers $\left(1 \mathrm{~mm}^{3}\right)$, griddled, sieved, and made up into the cell suspension. The cells were centrifuged at $1,500 \mathrm{~g}$ for $5 \mathrm{~min}$, and treated with $150 \mu 1 \mathrm{RNase} A$ at $37^{\circ} \mathrm{C}$ for $15-20 \mathrm{~min}$, suspended with PBS into the cell suspension $\left(1 \times 10^{6}\right.$ cells $\left./ \mathrm{ml}\right)$. Tumor DNA was then stained for 10 min with $100 \mu 1(50 \mu \mathrm{g} /$ $\mathrm{ml}$ ) propidium iodine (PI, Sigma). As the standard control of DNA examination with the health lung cells in nude mice, DNA value and apoptotic rate of the xenograft cells in each group were determined by cell apoptotic detection kit (BioDev Co., China) and fluorescent activated cell sorter (420 type FACS Flow cytometry, Becton-Dickinson, CA). Ten separate experiments were performed.

Immunohistochemistry in vivo. Proliferating cell nuclear antigen (PCNA), vascular endothelial growth factor (VEGF), angiopoietin-2 (Ang-2), thrombospondin (TSP), tissue inhibitor of metalloproteinase-2 (TIMP-2) protein products from the xenografted tumor cells of each group were determined by SABC method. The paraffin sections $(4 \mu \mathrm{m})$ from each group were dehydrated in xylene and graded ethanol series, were added in order with primary antibody [PCNA (mouse monoclonal antibody, Neomarker, USA, 1:200); VEGF (mouse monoclonal antibody, Neomarker), Ang-2 (goat polyclonal antibody, Santa Cruz, USA), TSP (mouse monoclonal antibody, Chemicon, USA), TIMP-2 [rabbit polyclonal antibody, Wuhan Boster Co., China); 1:100)], biotinylated secondary antibody (horse serum 1:200, Vector, USA; or goat serum 1:100, Wuhan Boster Co.), SABC reagents and DAB solution, respectively. Then, sections were rinsed in distilled water, dehydrated through alcohol and xylene and mounted coverslip using a permanent mount medium and observed by an optic microscope (Olympus, Japan). For negative control, the slides were treated with PBS in place of primary antibody. Ten sample slides in each group were chosen by analysis. More than ten visual fields were observed or $>500$ cells were counted per slide. The MVD of the xenograft tumors associating with the expression of these proteins, tumor volume, and PCNA/apoptosis ratio was evaluated simultaneously.

RT-PCR analysis in vivo. Expression of VEGF, Ang-2, TSP-1, TIMP-2 mRNAs from the xenografted tumors in the control and NCTD $\left(1 / 5 \mathrm{LD}_{50}\right.$ dose) groups were determined by RT-PCR assay. RT-PCR was performed as described by the manufacturer. Total RNA was extracted from the xenografted tumors using the TRIzol reagent. Concentration of RNA was determined by the absorption at $260 \mathrm{~nm}$. The primers for amplification were designed and synthesized by Shanghai Boya Biotech Co. The primers for VEGF, Ang-2, TSP-1, TIMP-2 and GAPDH were as follows: VEGF (408 bp) 5'-TGG GGC CTC CGA ACC ATG A-3' (sense); 5'-CCT GGT GAG AGA TCT GGT TC-3' (anti-sense); Ang-2 (304 bp) 5'-TGG GAT TTG GAT ACC CTT CA-3' (sense); 5'-CCA GCC TCC TGT TAG CAT TT-3' (anti-sense); TSP-1 (492 bp) 5'-ACC GCA TTC CAG AGT CTG GC3' (sense); 5'-AGT GGG ACG TCC AAC TCA GC-3' (anti- sense); TIMP-2 (368 bp) 5'-GGC AAG ATG CAC ATT ACC-3' (sense); 5'-TTG ACA TCC CTT CCT GGA-3' (anti-sense); GAPDH (452 bp) 5'-ACC ACA GTC CAT GCC ATC AC-3' (sense); 5'-TCC ACC ACC CTG TTG CTG TA-3' (anti-sense). Polymerse chain reactions were performed in a $20-\mu 1$ reaction volume. RT-PCR reaction was run in the following condition: at $94^{\circ} \mathrm{C}$ for $3 \mathrm{~min}, 1$ circle; at $94^{\circ} \mathrm{C}$ for $1 \mathrm{~min}$, at $72^{\circ} \mathrm{C}$ for $1 \mathrm{~min}$, 30 circle; at $72^{\circ} \mathrm{C}$ for $7 \mathrm{~min}, 1$ circle. The Tm of VEGF, Ang-2, TSP-1, TIMP-2 were $61^{\circ} \mathrm{C}, 57^{\circ} \mathrm{C}, 60^{\circ} \mathrm{C}, 53^{\circ} \mathrm{C}$ respectively. PCR products $(10 \mu \mathrm{l})$ was placed onto $15 \mathrm{~g} / \mathrm{l}$ agarose gel and observed by EB staining using the Gel-Pro analyzer.

Statistical analysis. Statistical analyses were performed using SPSS 11.5 and Microsoft Excel Office 2007 for Windows. All data were presented as mean \pm SD. Statistical differences were evaluated using Student's t-test or $\chi^{2}$ test. $P<0.05$ was considered statistically significant. The MVD of the xenografts associating with expression of angiogenic factors, tumor volume and PCNA/apoptosis ratio was evaluated by correlation analysis. Survival curves were calculated with the Kaplan-Meier method and were compared using the log-rank test.

\section{Results}

NCTD inhibits HUVEC growth in vitro. As shown in Fig. 1, HUVECs cultured in the culture medium without VEGF and the ECGM with VEGF began to growth at $6 \mathrm{~h}$, maturing at $24 \mathrm{~h}$. But HUVECs cultured in ECGM with VEGF, i.e., VEGF-induced proliferation of HUVECs was more active, abundant and intensive. The cells were predominantly of shuttle- or polygon-shape, or accumulation, with abundant cytoplasm, clear nuclei; and presented yellow-brown positive reactant in cytomembrane with $\mathrm{CD}_{34}$ immunocytochemical staining under an inversion optic microscope. The effect of NCTD on HUVECs growth was examined at doses between 0 and $120 \mu \mathrm{g} / \mathrm{ml}$. The inhibitory effect of NCTD at low concentrations $(5 \mu \mathrm{g} / \mathrm{ml})$ on cells was not obvious; but as concentration increased, proliferation and growth of cells was markedly inhibited by NCTD. NCTD inhibited growth of HUVECs in a dose-dependent manner, but without difference between the cells cultured in the culture medium without VEGF and those in the ECGM with VEGF. IC $_{50}$ of NCTD for HUVECs was $51.66 \mu \mathrm{g} / \mathrm{ml}$.

NCTD induces HUVECs apoptosis in vitro. The morphological changes of cell apoptosis induced by NCTD at dose of $\mathrm{IC}_{50}$ with Hoechst 33258 immunofluorescence staining, such as intensified blue-fluorescence nucleoli, marginal collecting, nucleolus cataclysm, chromatin redistributing and typical apoptotic bodies were observed under a fluorescent microscope (Fig. 1E and G). NCTD induced apoptosis of HUVECs in a time-dependent manner (Fig. 1F and $\mathrm{H}$ ); the apoptotic percentage of HUVECs in NCTD, ES or NCTD+ES group was respectively higher than that of control group (Fig. $1 \mathrm{H} ; \mathrm{P}<0.05$ ); moreover, there was no significant difference on apoptosis among NCTD, ES and NCTD+ES groups. The morphological changes of cell apoptosis similar with NCTD group were observed in ES or NCTD+ES group, but weaken fluorescence and without apoptotic in control group (Fig. 1G). It was deduced that NCTD can effectively inhibit the growth of HUVEC by inducement of HUVEC apoptosis in a dose- and time-dependent manner. 
A

B

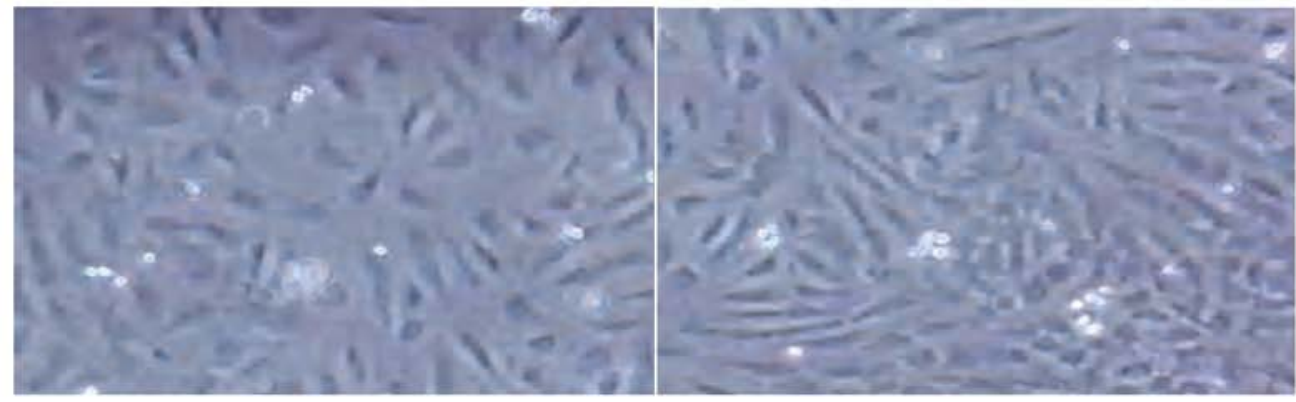

C

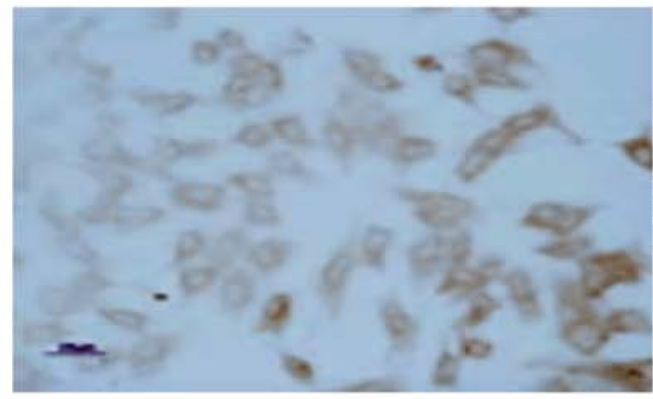

E

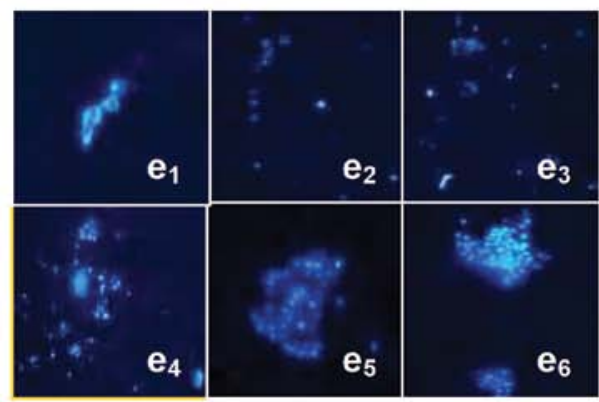

G

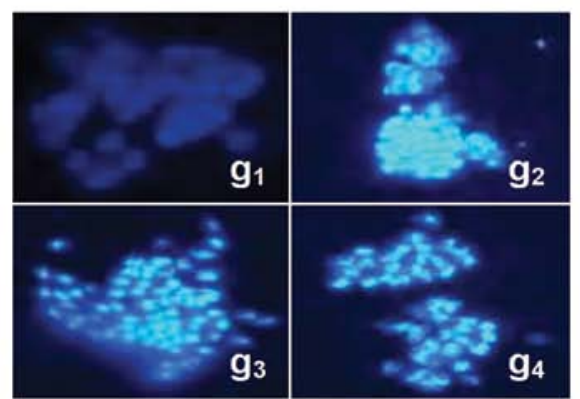

D

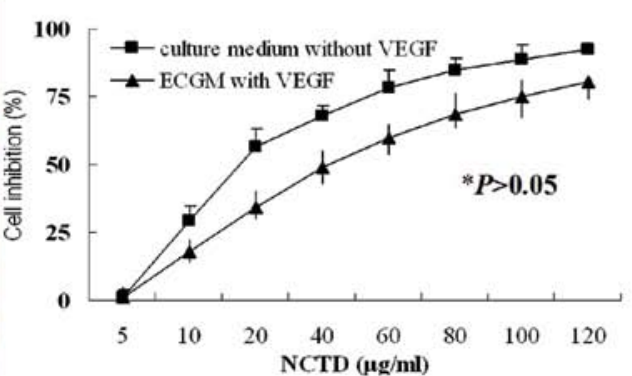

F

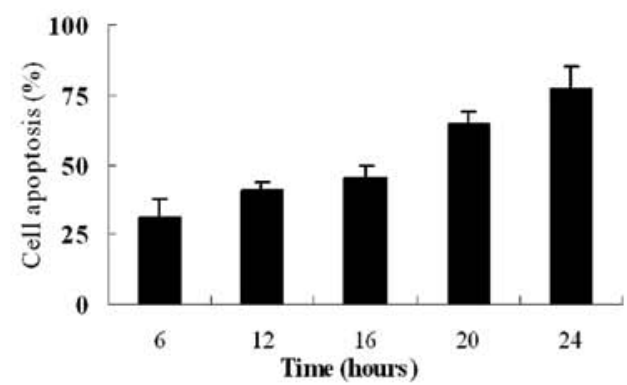

H

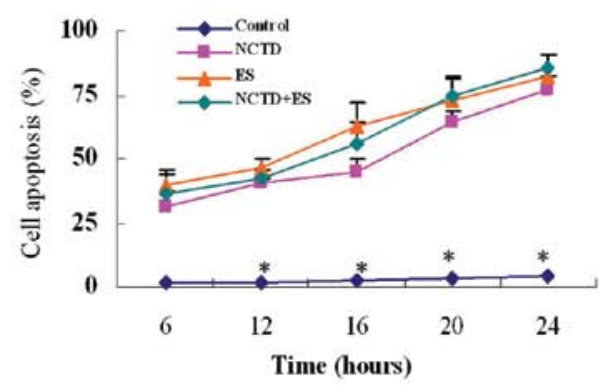

Figure 1. Identifying of HUVECs and the effect of NCTD on HUVEC growth and apoptosis in vitro. (A and B) Histomorphologic structures (magnification $\mathrm{x} 200$ ) of HUVECs cultured in the culture medium without VEGF (A) and the ECGM with VEGF (B) at $24 \mathrm{~h}$. (C) Yellow-brown positive reactant in cytomembrane with $\mathrm{CD}_{34}$ immunocytochemical staining under an inversion optic microscope (magnification $\mathrm{x} 400$ ). (D) The dose-response curves of NCTD effect on HUVECs cultured in the culture medium without VEGF and the ECGM with VEGF. Cell number was counted by the MTT method. (E) The morpho-logical changes of HUVECs' apoptosis in NCTD group with Hoechst 33258 immunofluorescence staining under a fluorescent microscope (e $e_{1}$, typical apoptotic changes, intensified blue-fluorescence nucleoli and apoptotic body, magnification x $400 ; \mathrm{e}_{2}, 6 \mathrm{~h} ; \mathrm{e}_{3}, 12 \mathrm{~h} ; \mathrm{e}_{4}, 16 \mathrm{~h} ; \mathrm{e}_{5}, 20 \mathrm{~h} ; \mathrm{e}_{6}, 24 \mathrm{~h} ; \mathrm{e}_{2-6}$, magnification x200). (F) The percentage of cell apoptosis induced by NCTD at dose of $\mathrm{IC}_{50}$ in a time-dependent manner. (G) The morphological changes of HUVECs apoptosis in control $\left(\mathrm{g}_{1}\right)$, ES $\left(\mathrm{g}_{2}\right)$, NCTD $\left(\mathrm{g}_{3}\right)$ and NCTD+ES $\left(\mathrm{g}_{4}\right)$ groups. $(\mathrm{H})$ The curves of HUVEC apoptosis in control, ES, NCTD and NCTD+ES groups in a timedependent manner ( $\mathrm{P}<0.05$, vs. NCTD, ES and NCTD+ES groups).

NCTD inhibits HUVEC migration in vitro. The effects of NCTD on migration of the cultured HUVECs, i.e., cell migration distance onto the scraped areas and migrated cells were measured by scraping line method under an inversion microscope. As shown in Fig. 2, after treatment with NCTD for $24 \mathrm{~h}$ and along with increase of the NCTD concentration, migrated cells $\left(\mathrm{P}=0.000\right.$, Fig. $\left.2 \mathrm{Bb}_{1}\right)$ onto the scraped areas were decreased, cell migration distance $\left(\mathrm{P}=0.000\right.$, Fig. $\left.2 \mathrm{Bb}_{2}\right)$ was 
A

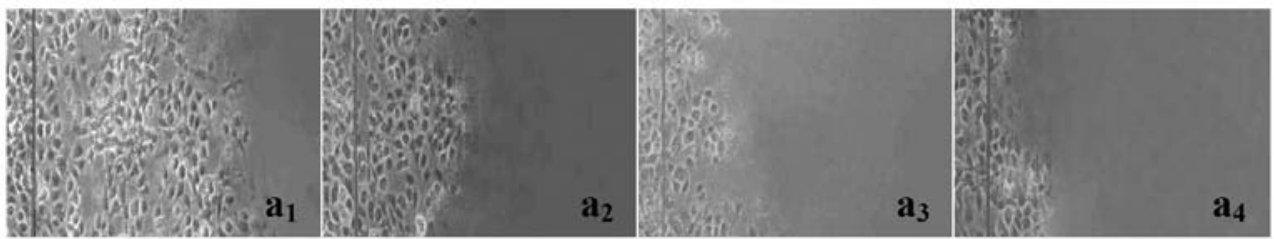

B
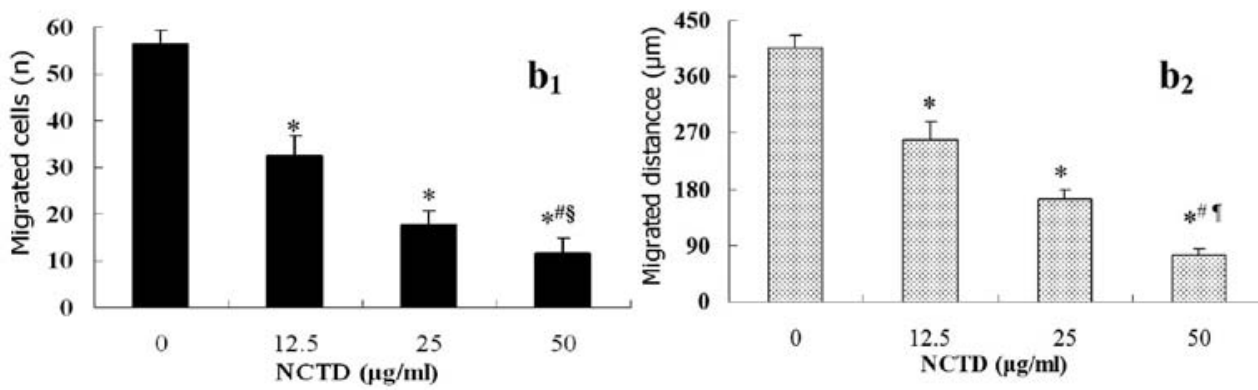

Figure 2. The inhibitory effect of NCTD on HUVEC migration for $24 \mathrm{~h}$ in vitro. (A) Migration assay of HUVECs by scraping line method under an inversion optic microscope, magnification x200 ( $\mathrm{a}_{1}$, control group; $\mathrm{a}_{2}, 12.5 \mathrm{NCTD} \mu \mathrm{g} / \mathrm{ml} ; \mathrm{a}_{3}, 25.0 \mathrm{NCTD} \mu \mathrm{g} / \mathrm{ml}$; $\mathrm{a}_{4}, 50.0 \mathrm{NCTD} \mu \mathrm{g} / \mathrm{ml}$ ). (B) The effect of NCTD on HUVEC migration in a dose-dependent manner $\left(b_{1}\right.$, migrated cells onto the scraped areas; $b_{2}$, migration distance of cells onto the scraped areas in different groups). ${ }^{*} \mathrm{P}=0.000$, vs. control group; ${ }^{\#} \mathrm{P}=0.000$, vs. $12.5 \mu \mathrm{g} / \mathrm{ml}$ NCTD group; ${ }^{\S} \mathrm{P}=0.015 ;{ }^{\mathrm{g}} \mathrm{P}=0.034$, vs. $25.0 \mu \mathrm{g} / \mathrm{ml} \mathrm{NCTD}$ group.

A

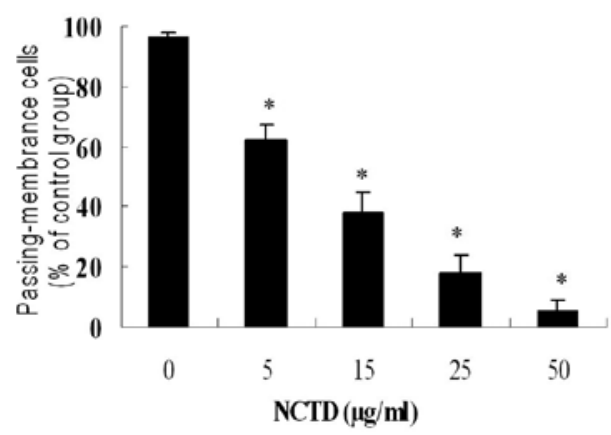

B

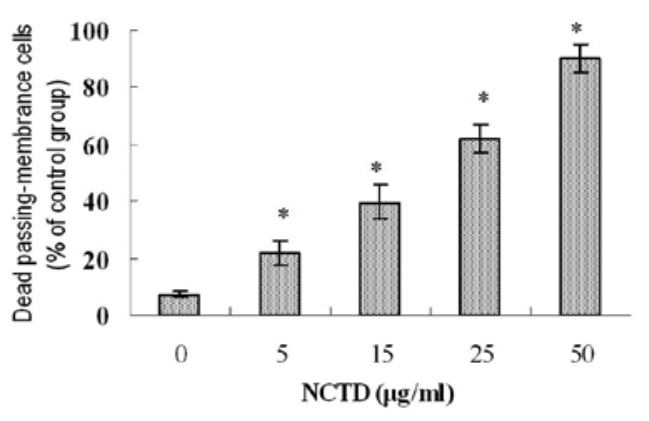

Figure 3. The inhibitory effect of NCTD on HUVEC invasion for $24 \mathrm{~h}$ in vitro. Invasion assay of HUVECs was done by the matrigel invasion experiment. (A) The histogram of passing membrane HUVECs. (B) The histogram of dead passing-membrane HUVECs. As its concentration increased, the passing membrane cells in NCTD group markedly decreased, the dead passing-membrane cells obviously increased, when compared with control group ( $\mathrm{P}<0.01$, vs. control group).

shortened significantly, when compared with control group. It was shown that NCTD inhibited significantly HUVEC migration in a dose-dependent manner in vitro.

NCTD inhibits HUVEC invasion in vitro. As shown in Fig. 3, HUVECs in untreated control group passed more of the membrane and had more invasive capability in vitro; NCTD began to inhibit the invasion of HUVECs at the concentration of $5 \mu \mathrm{g} / \mathrm{ml}$ and as its concentration increased, their passing membrane cells markedly decreased, the trypan blue dyed cells, namely the dead passing-membrane cells obviously increased $(\mathrm{P}<0.01)$. At $50 \mu \mathrm{g} / \mathrm{ml}$ of NCTD, the invasive action of HUVECs was inhibited almost completely. Thus, NCTD inhibited significantly HUVEC invasion in a dose-dependent manner. It was shown that NCTD clearly inhibited the in vitro invasive capability simulating human basement membrane of HUVECs.
NCTD inhibits HUVEC tube formation in vitro. In our experiments, we evaluated the inhibitory effects of NCTD on tube formation of HUVECs in vitro. As shown in Fig. 4, HUVECs in control group form a well-arranged network of tubes within $24 \mathrm{~h}$, while this effect was significantly decreased in the presence of NCTD $(\mathrm{P}<0.05, \mathrm{P}<0.01$ or $\mathrm{P}<0.001)$, with increased inhibition of HUVEC tube formation as the concentration increasing $(\mathrm{P}<0.05, \mathrm{P}<0.01$ or $\mathrm{P}<0.001)$, similarly to the result of ES group. Thus, NCTD was found to have significant inhibitory effects on the capillary-like tube formation of HUVECs in vitro.

NCTD inhibits chicken embryo CAM angiogenesis in vivo. We also evaluated the inhibitory effects of NCTD on the angiogenesis of chicken embryo CAM in vivo. As shown in Fig. 5, alive chicken embryos and chicken embryo CAM capillaries were significantly less in 1.0-5.0 $\mathrm{mg} / \mathrm{ml}$ NCTD groups than in control group (Fig. 5B, $\mathrm{P}<0.05$ ), with destroyed, pale, illegible 
A

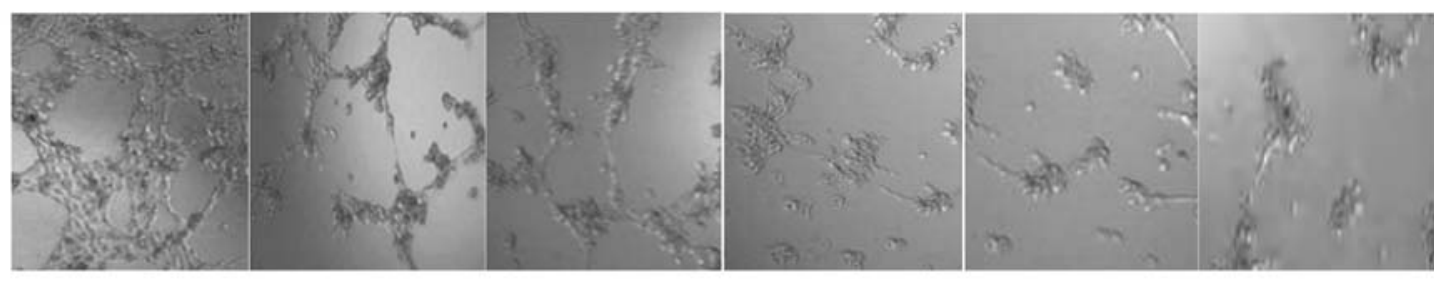

Control group

$5 \quad 10$

5

50

ES group

NCTD $(\mu \mathrm{g} / \mathrm{ml})$ group

B

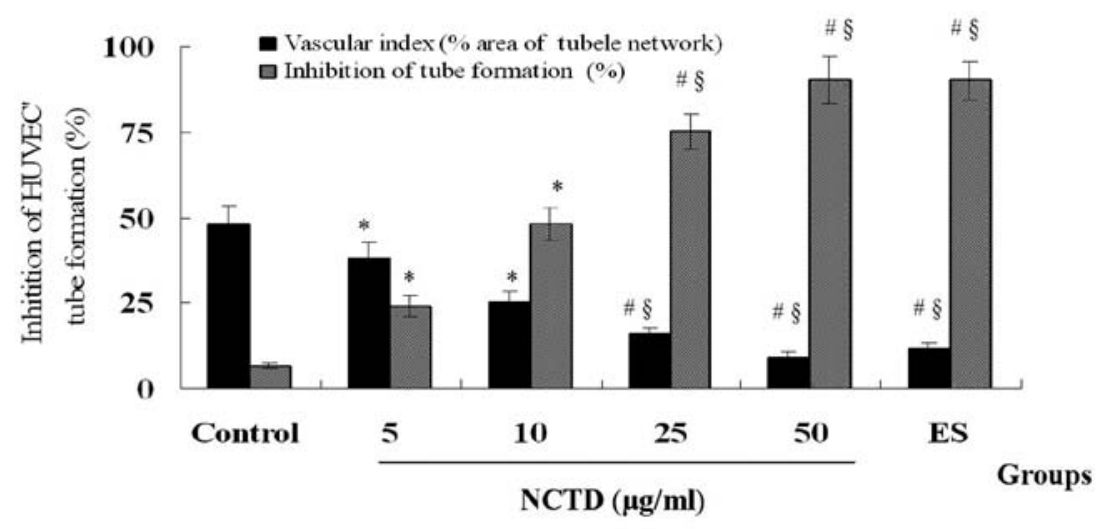

Figure 4. The inhibitory effect of NCTD on HUVEC tube formation in vitro. (A) Representative photographs of HUVEC tube formation in vitro (magnification x100). (B) The inhibitory effect of NCTD on HUVEC tube formation. Vascular index was significantly decreased in the presence of NCTD or ES, with increased inhibition of HUVEC tube formation as the concentration increased. ${ }^{*} \mathrm{P}<0.05$, vs. control group; ${ }^{*} \mathrm{P}<0.001$, vs. control group; ${ }^{\S} \mathrm{P}<0.01$, vs. $5-10 \mu \mathrm{g} / \mathrm{ml} \mathrm{NCTD}$ groups.

A
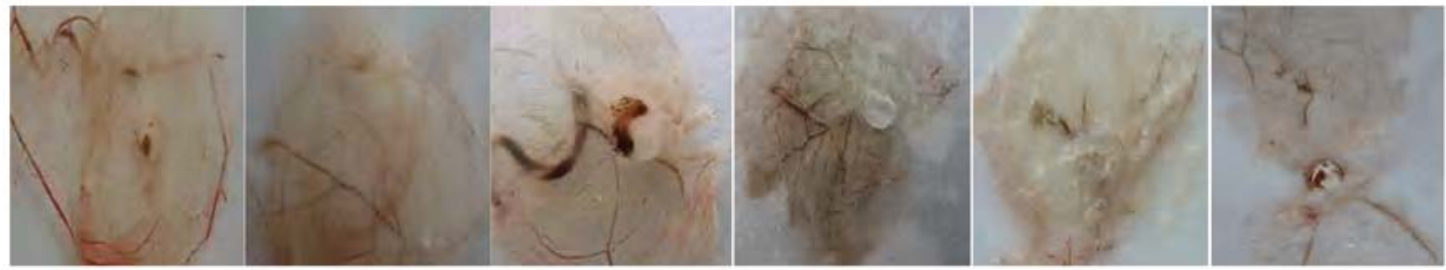

Control group

0.5

2.5 5.0

ES group

B

NCTD $(\mathrm{mg} / \mathrm{ml})$ group

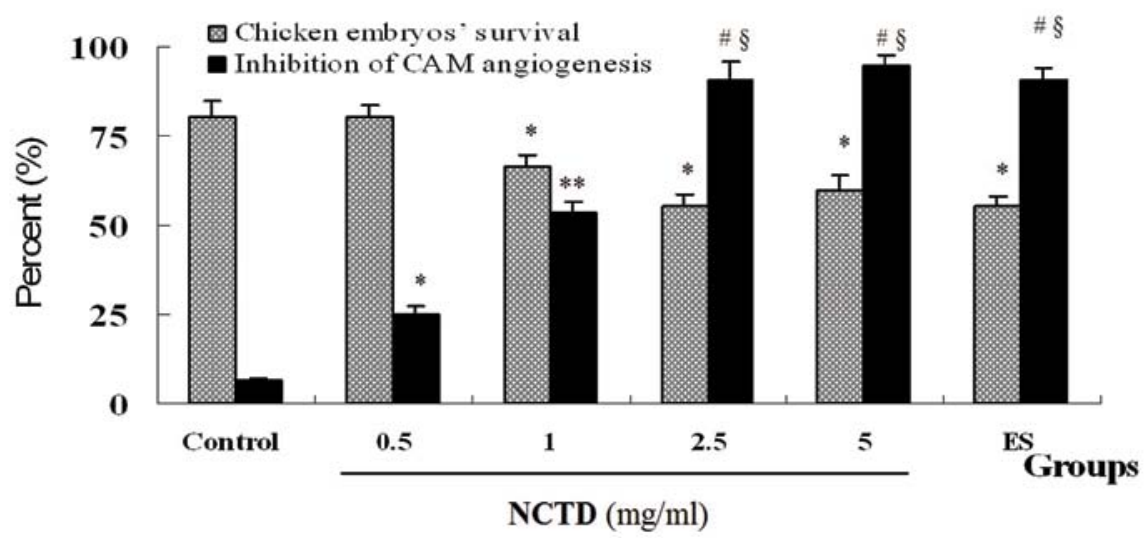

Figure 5. The inhibitory effect of NCTD on embryonic CAM angiogenesis in vivo. (A) Representative photographs of chicken embryo survival and CAM angiogenesis in vivo (digital camera, Canon 5D MarkII, 1280x960). (B) The histogram of the effect of NCTD on chicken embryo survival and CAM angiogenesis. Alive chicken embryos and CAM capillaries significantly decreased in 1.0-5.0 mg/ml NCTD groups, with increased inhibition of CAM angiogenesis as the concentration increased ${ }^{*} \mathrm{P}<0.05,{ }^{* *} \mathrm{P}<0.01 ;{ }^{*} \mathrm{P}<0.001$, vs. control group; ${ }^{\circledR} \mathrm{P}<0.01$, vs. $0.5-1.0 \mathrm{mg} / \mathrm{ml}$ NCTD groups. 
A

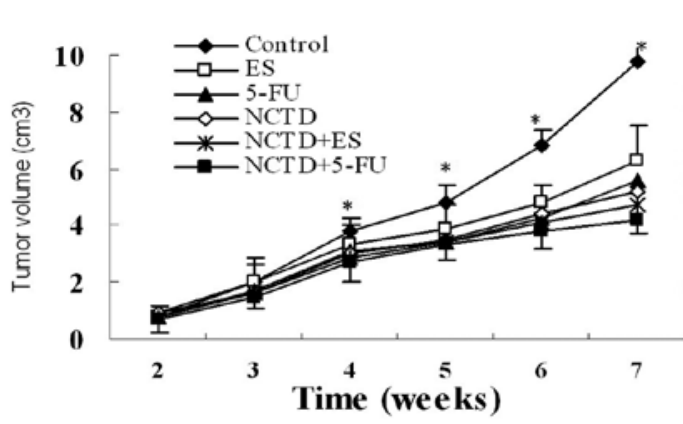

C

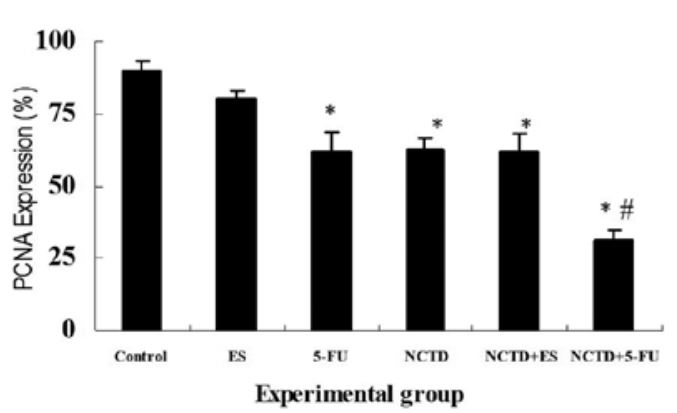

B

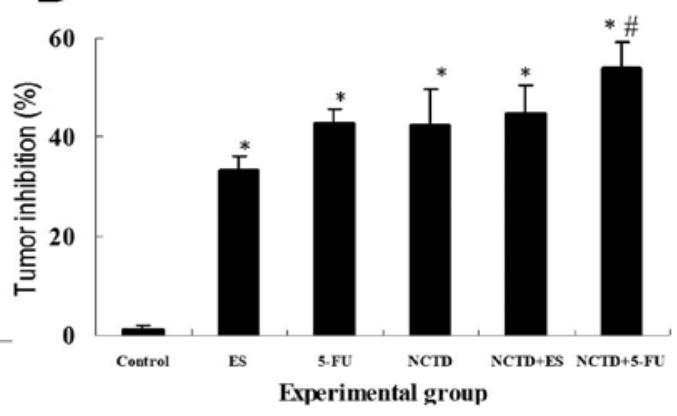

D

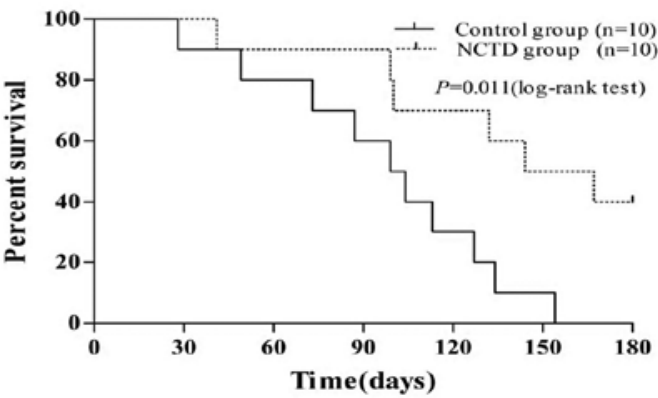

Figure 6. NCTD inhibits the growth and proliferation of the xenografts effectively and safely in vivo: the curves of the tumor growth inhibition (A), tumor inhibition rate (B), PCNA expression (C) of the xenograft tumors in various groups, and Kaplan-Meier survival curves for the xenograft mice in control group and NCTD group (D; log-rank test, $\mathrm{P}=0.011)$. ${ }^{*} \mathrm{P}<0.01$, vs. control group; \#P<0.05, vs. ES, 5-FU, NCTD, NCTD+ES groups; ${ }^{\S} \mathrm{P}<0.05$, vs. ES or 5-FU groups.

Table I. The xenograft MVD and its correlation with tumor volume, PCNA/apoptosis ratio, and expression of angiogenic (VEGF, Ang-2) and antiangiogenic (TSP, TIMP-2) proteins (mean \pm SD).

\begin{tabular}{|c|c|c|c|c|c|c|c|c|}
\hline \multirow{2}{*}{ Group } & \multirow{2}{*}{$\begin{array}{l}\text { Mice } \\
\text { (n) }\end{array}$} & \multirow{2}{*}{$\begin{array}{l}\text { MVD } \\
\text { (n) }\end{array}$} & \multirow{2}{*}{$\begin{array}{l}\text { Tumor volume } \\
\qquad\left(\mathrm{cm}^{3}\right)\end{array}$} & \multirow{2}{*}{$\begin{array}{c}\text { PCNA/apoptosis } \\
\text { ratio }\end{array}$} & \multicolumn{4}{|c|}{ Protein expression $(\%)$} \\
\hline & & & & & VEGF & Ang-2 & TSP & TIMP-2 \\
\hline Control & 10 & $17.6 \pm 3.2$ & $9.8 \pm 0.6$ & $16.4 \pm 1.7$ & $44.7 \pm 4.2$ & $36.8 \pm 8.7$ & $14.7 \pm 1.1$ & $56.7 \pm 0.8$ \\
\hline $5-\mathrm{FU}$ & 10 & $15.8 \pm 5.9$ & $5.6 \pm 0.6^{\mathrm{b}}$ & $7.1 \pm 3.6^{\mathrm{c}}$ & $41.0 \pm 4.4$ & $31.7 \pm 1.8$ & $99.1 \pm 2.8$ & $110.6 \pm 18.4$ \\
\hline $\mathrm{ES}$ & 10 & $4.5 \pm 2.1^{\mathrm{a}, \mathrm{f}}$ & $6.3 \pm 1.2^{\mathrm{b}}$ & $10.8 \pm 4.0^{\mathrm{c}}$ & $31.9 \pm 4.4^{\mathrm{e}}$ & $21.5 \pm 2.9^{\mathrm{e}}$ & $154.9 \pm 7.8^{\mathrm{e}}$ & $178.4 \pm 6.8^{\mathrm{e}}$ \\
\hline NCTD & 10 & $4.1 \pm 1.4^{\mathrm{a}, \mathrm{f}}$ & $5.6 \pm 0.4^{\mathrm{b}}$ & $4.8 \pm 2.1^{\mathrm{c}}$ & $32.3 \pm 5.6^{\mathrm{e}}$ & $22.6 \pm 3.7^{\mathrm{e}}$ & $166.9 \pm 8.9^{\mathrm{e}}$ & $180.4 \pm 4.1^{\mathrm{e}}$ \\
\hline $\mathrm{NCTD}+5-\mathrm{FU}$ & 10 & $3.8 \pm 1.7^{\mathrm{a}, \mathrm{f}}$ & $4.5 \pm 1.1^{\mathrm{b}}$ & $1.7 \pm 1.2^{\mathrm{d}}$ & $31.8 \pm 3.8^{\mathrm{e}}$ & $23.6 \pm 2.5^{\mathrm{e}}$ & $136.1 \pm 4.0^{\mathrm{e}}$ & $166.6 \pm 4.4^{\mathrm{e}}$ \\
\hline NCTD+ES & 10 & $3.0 \pm 1.5^{\mathrm{a}, \mathrm{f}}$ & $5.4 \pm 0.9^{\mathrm{b}}$ & $1.7 \pm 1.3^{\mathrm{d}}$ & $29.7 \pm 3.8^{\mathrm{e}}$ & $19.8 \pm 4.4^{\mathrm{e}}$ & $172.7 \pm 9.6^{\mathrm{e}}$ & $187.6 \pm 9.1^{\mathrm{e}}$ \\
\hline
\end{tabular}

${ }^{\mathrm{a}} \mathrm{P}<0.01$, vs. control and 5-FU groups; ${ }^{\mathrm{b}} \mathrm{P}<0.05$, vs. control group; ${ }^{\mathrm{c}} \mathrm{P}<0.01$, vs. control group; ${ }^{\mathrm{d}} \mathrm{P}<0.05$, vs. 5-FU, ES, NCTD groups; ${ }^{\mathrm{e}} \mathrm{P}<0.01$, vs. control and 5-FU groups. ${ }^{\mathrm{f}} \mathrm{P}<0.05$, positive correlation between MVD and tumor volume ( $\left.\mathrm{r}=0.985\right)$, PCNA/apoptosis ratio ( $\left.\mathrm{r}=0.956\right)$, VEGF $(\mathrm{r}=0.977)$ or Ang-2 ( $\mathrm{r}=0.966)$; negative correlation between MVD and TSP ( $\mathrm{r}=-0.956)$ or TIMP-2 ( $\mathrm{r}=-0.957)$.

and hyaline microvessels, or no neo-angiogenesis in $2.5-5.0 \mathrm{mg} /$ ml NCTD groups and in ES group (Fig. 5B); whereas clear, non-inhibited CAM angiogenesis in control group, illegible and pale in $0.5-1.0 \mu \mathrm{g} / \mathrm{ml}$ NCTD groups. The inhibitory rates of angiogenesis of chicken embryo CAM in NCTD groups at a dose of $2.5 \mathrm{mg} / \mathrm{ml}(90.9 \pm 4.9 \%)$ and $5.0 \mathrm{mg} / \mathrm{ml}(94.8 \pm 3.1 \%)$ were significantly increased when compared with the control group $(6.3 \pm 0.9 \%, \mathrm{P}<0.001)$ and the low-dose NCTD groups $(\mathrm{P}<0.05)$, similarly to the result of ES group (Fig. 5B). A positive correlation was observed between the concentration of NCTD and the antiangiogenesis of CAM $(r=0.89, \mathrm{t}=3.453, \mathrm{P}<0.05)$. It was deduced that NCTD had inhibitory effects on the angiogenesis of chick embryonic CAM in vivo, and destroyed the formed CAM capillaries directly.

NCTD inhibits growth of the xenografts effectively and safely in vivo. Depending on the acute toxicity test and the $\mathrm{LD}_{50}$ formula, $\mathrm{LD}_{50}$ of NCTD for small white rats was calculated as $139.96 \mathrm{mg} / \mathrm{kg}$. One fifth of NCTD $\mathrm{LD}_{50}$ was safe dose for nude mice, because the mice were all alive at the end of the experimens, with prolonged survival time in NCTD group compared to the control group (log-rank test, $\mathrm{P}=0.011$; Fig. 6D). Also, as 


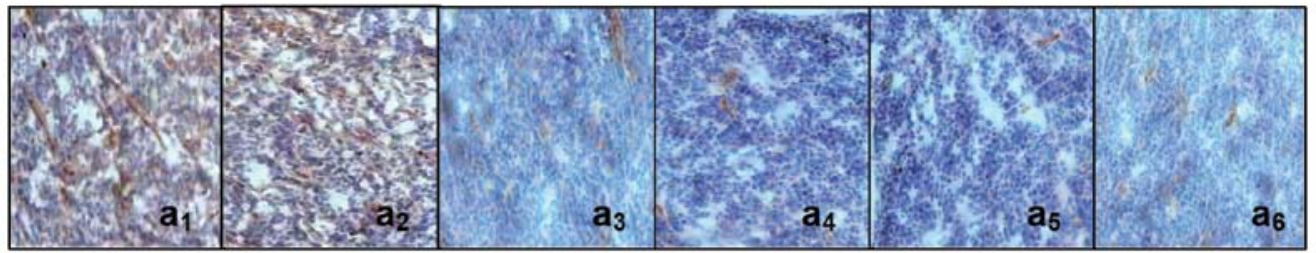

B

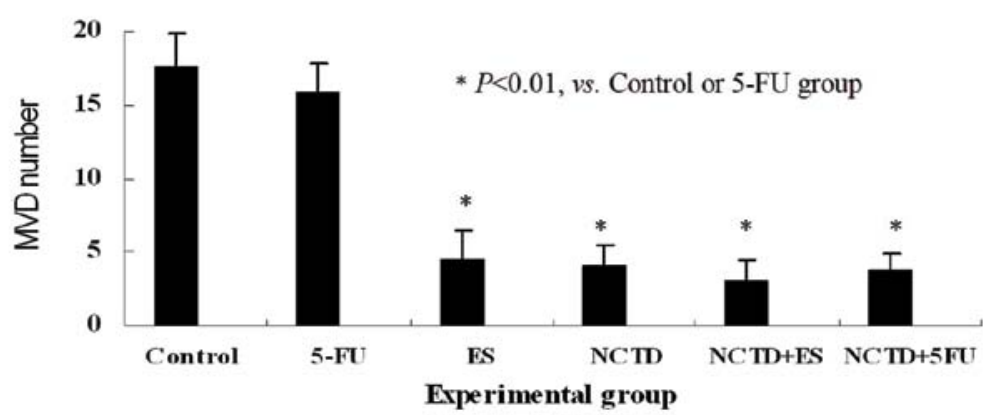

Figure 7. The effect of NCTD on the xenograft microvessels and MVD in vivo. (A) $\mathrm{CD}_{34}$ immunohistochemistry staining, magnification $\mathrm{x} 100$. (B) The MVD numbers of the xenografts in various groups in vivo. The higher MVD, with strip-shaped brown and dense microvessels, of the xenografts in control $\left(\mathrm{a}_{1}\right)$ and 5-FU $\left(a_{2}\right)$ groups; the lower MVD, with few and thin microvessels, in NCTD $\left(a_{3}\right)$, ES $\left(a_{4}\right), N C T D+5-F U\left(a_{5}\right)$, and NCTD+ES $\left(a_{6}\right)$ groups $(B$, all P<0.01), but no significant difference on MVD numbers among NCTD, ES, NCTD+5-FU, and NCTD+ES groups.

shown in Fig. 6A-C and Table I, the volume of the xenografts in NCTD group was significantly smaller than that of the control group $(\mathrm{P}<0.01)$, with increased tumor inhibitory rate $(\mathrm{P}<0.05)$, decreased PCNA expression $(\mathrm{P}<0.05)$, not significantly different from those of the 5-FU, ES, and NCTD+ES groups. But it was shown that there was significant difference $(\mathrm{P}<0.05)$ in tumor volume, tumor inhibitory rate and PCNA expression in NCTD+5-FU group in comparison with other groups. In addition, a positive correlation was observed between the decreased tumor volume or the increased tumor inhibition and the PCNA expression $(r=0.912, t=5.556, \mathrm{P}<0.01)$ in the xenografts of NCTD group. Thus, it was shown that NCTD inhibits proliferation and growth of the xenografts effectively and safely in vivo.

NCTD destroys angiogenesis of the xenografts in vivo. Tumor cytoclasis, apoptosis among the vessels with rebirth tumor cells, invaded and destroyed microvessel profile among the apoptotic tumor cells were observed in the NCTD group in comparison with the control group; moreover, dense microvessels with stripshaped brown staining by $\mathrm{CD}_{34}$ immunohistochemistry were visualized in control or 5-FU group (Fig. 7A). Also, as shown in Fig. 7B, the MVD numbers of NCTD group was 4.1 1.4 , significant lower than those of control group (17.6 \pm 3.2$)$ and 5-FU group (15.8 \pm 5.9 )(both $\mathrm{P}<0.01$ ), but not significant different from those of NCTD+5-FU group (3.8 \pm 1.7$)$, ES group (4.5 \pm 2.1$)$ and NCTD+ES group (3.0 \pm 1.5$)$ (all, $\mathrm{P}>0.05)$. Also, the MVD of the xenografts was positively related with tumor volume, PCNA/ apoptosis ratio, respectively (both $\mathrm{P}<0.05$ ) after NCTD treatment for the xenografts in nude mice (Table I).

NCTD decreases vascular perfusion of the xenografts in vivo. Two-mm-interval horizontal scanning of two different xenografts (control group and NCTD group) was conducted to compare tumor signal intensities between mice by dynamic micro-MRA with the HAS-Gd-DTPA intravascular macromolecular MRI contrast agent. As shown in Fig. 8, the tumor marginal area of the xenografts in control group exhibited gradually a high-intensity signal that completely surrounded the xenograft tumor, a finding consistent with angiogenesis. However, the xenografts in NCTD group exhibited a low intensity signal or a lack of signal, a result consistent with marginal micro-vascular damage, tumor center necrosis and disappearance of nuclei. Examination of the hemodynamics of angiogenesis in the xenografts in vivo showed that NCTD decreases vascular perfusion of the xenografts in vivo.

NCTD affects the expression of angiogenic and antiangiogenic proteins/mRNAs. The expressions of VEGF, Ang-2, TSP, TIMP-2 proteins/mRNAs in xenograft tumor cells in various groups in vivo are shown in Fig. 9. The protein expression of VEGF and Ang-2 in NCTD group were both significantly lower than those of the control and 5-FU groups (all $\mathrm{P}<0.05$ ), the protein expression of TSP and TIMP-2 were both significantly higher than those of the control and 5-FU groups (all $\mathrm{P}<0.01$ ), however, not significantly different from those of the ES, NCTD+5-FU and NCTD+ES groups. The mRNA expression of VEGF and Ang-2 were significantly down-regulated, with significant up-regulated TSP-1 or TIMP-2 mRNA expression in the NCTD group in comparison with the control group (all $\mathrm{P}<0.05)$. Moreover, the MVD of the xenografts was positively correlated with the expression of VEGF or Ang-2 protein (both $\mathrm{P}<0.05)$, but negatively correlated with the expression of TSP or TIMP-2 protein (both $\mathrm{P}<0.05$ ) (Table I). The results showed that NCTD, similar to ES, effectively down-regulated the expression of the angiogenic factors such as VEGF and Ang-2, and up-regulated the expression of the antiangiogenic factors such as TSP and TMP-2, thus inhibiting the tumor angiogenesis and 
A
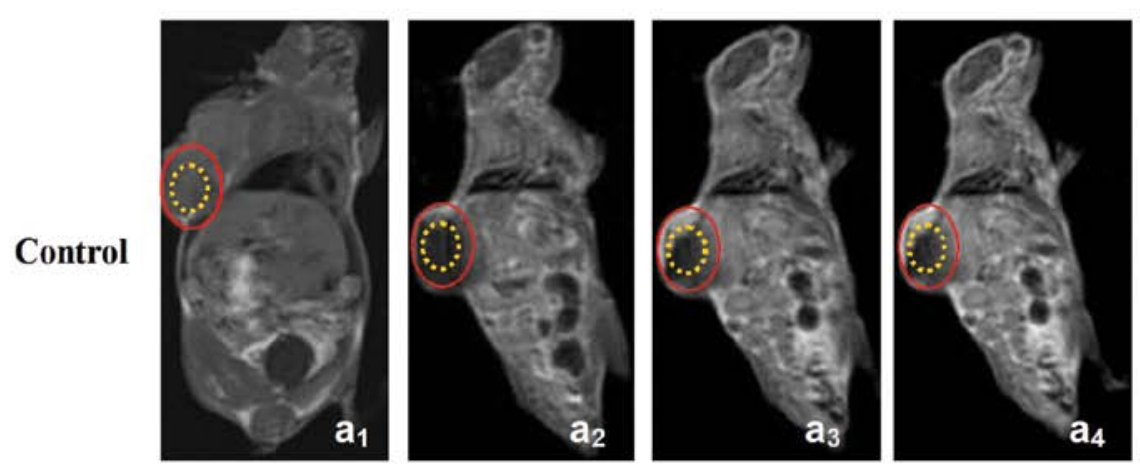

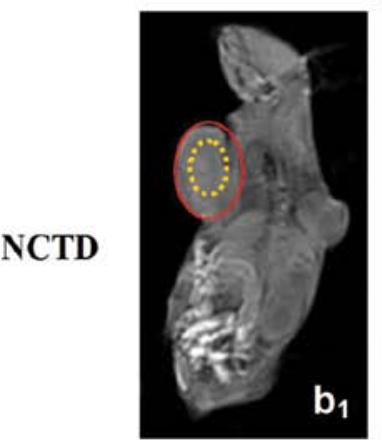

Pre

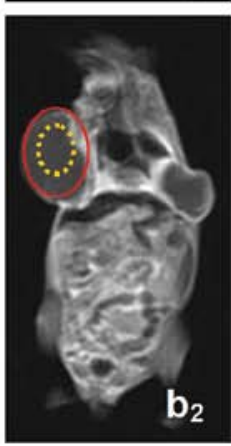

$5 \min$

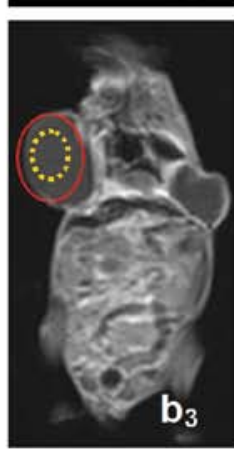

$10 \min$

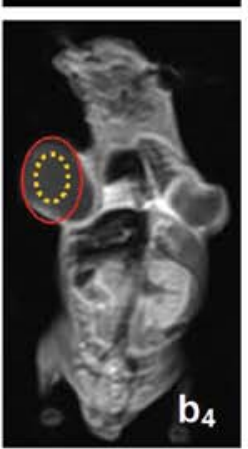

$15 \mathrm{~min}$

B

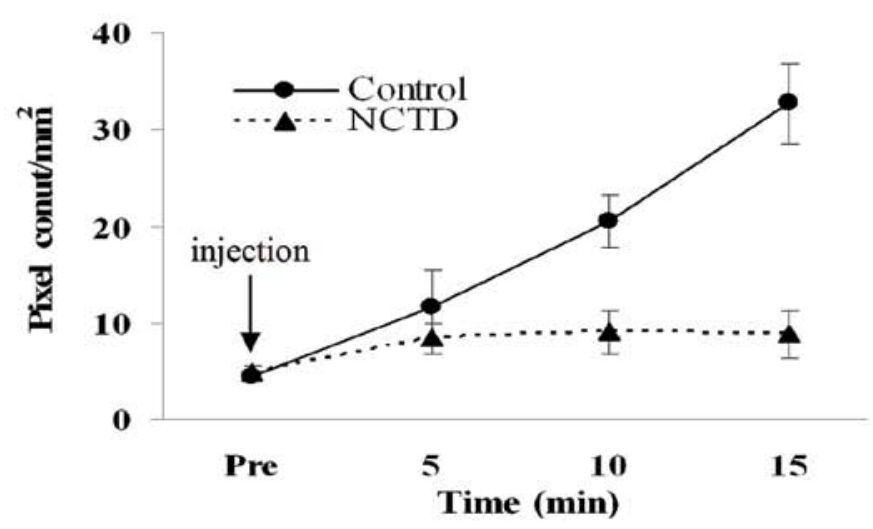

Figure 8. Dynamic micro-MRA and hemodynamic of angiogenesis of the xenografts in control ( $\left.\mathrm{a}_{1-4}\right)$ and NCTD groups $\left(\mathrm{b}_{1-4}\right)$ in vivo. $(\mathrm{A})$ The images were acquired before the injection of the contrast agents (HAS-Gd-DTPA, pre), 5, 10, and 15 min after injection. The tumor marginal area (red circle) in control group exhibited a signal that gradually increased in intensity. However, the marginal area (red circle) and the center region (yellow circle) of the xenografts in NCTD group exhibited a gradually decreased signal or a lack of signal in intensity. (B) Hemodynamic of angiogenesis of the xenografts in control and NCTD groups. All data are expressed as means \pm SD.

further inhibiting gallbladder cancer growth. But 5-FU group did not have this result.

\section{Discussion}

Angiogenesis, neovessels coming up into the tumor, is the basic model of blood supply for tumor, and essential nutrition and substance supply for tumor development and proliferation (53-55). Therefore, inhibition of blood vessel growth is a potential therapy for primary tumors. Drugs are used to treat tumors with the anti-vessel mechanism. In recent years research has focused on hot-spots and to cure carcinoma inhibition of vessel formation early by destroying tumor vessels $(12-23,56,57)$. As one of the inhibitory factors, ES is the 18-type collagen protein amino acid segment separated from the culture fluid of vessel endothelioma, a strong angiogenic inhibitor, which can especially inhibit endothelium cell proliferation, migration and tumor vessel generation inducing cell apoptosis to keep the primary or metastatic tumor dormancy status without growth $(56,57)$. Some angiogenesis inhibitors such as bevacizumab, sorafenib, erlotinib, sunitinib have been reported as adjuvant anti-tumor drug against metastatic colorectal cancer, non-small lung cancer, breast cancer, liver cancer, renal cell cancer, and advanced gastrointestinal stromal tumors (12-23). However, as a result of sole blockage of angiogenesis i.e., part of the complicated process of tumor growth and metastasis, antiangiogenic therapy has been rather modest $(24,25)$, leading to increased interest in developing more effective ways to 
A

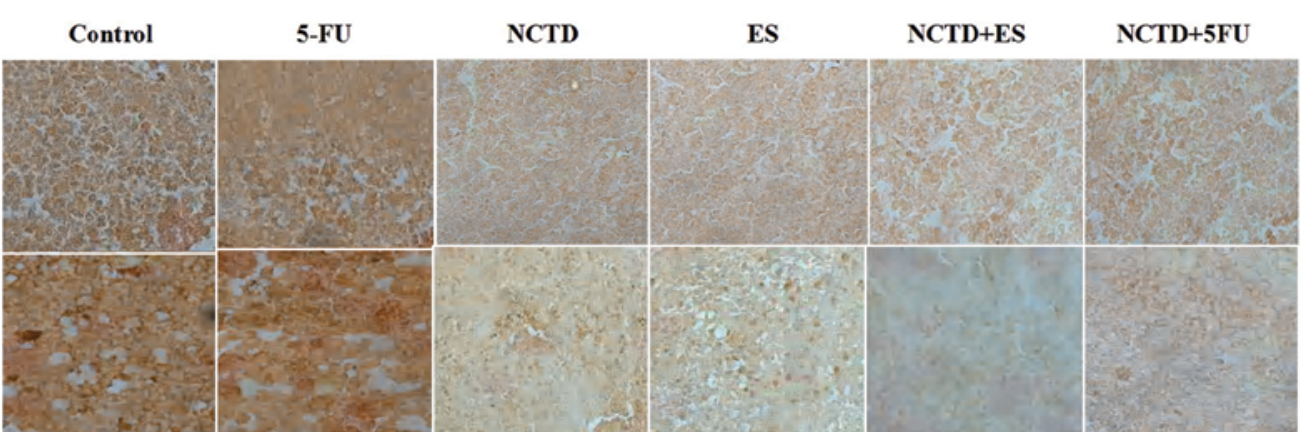

Ang-2
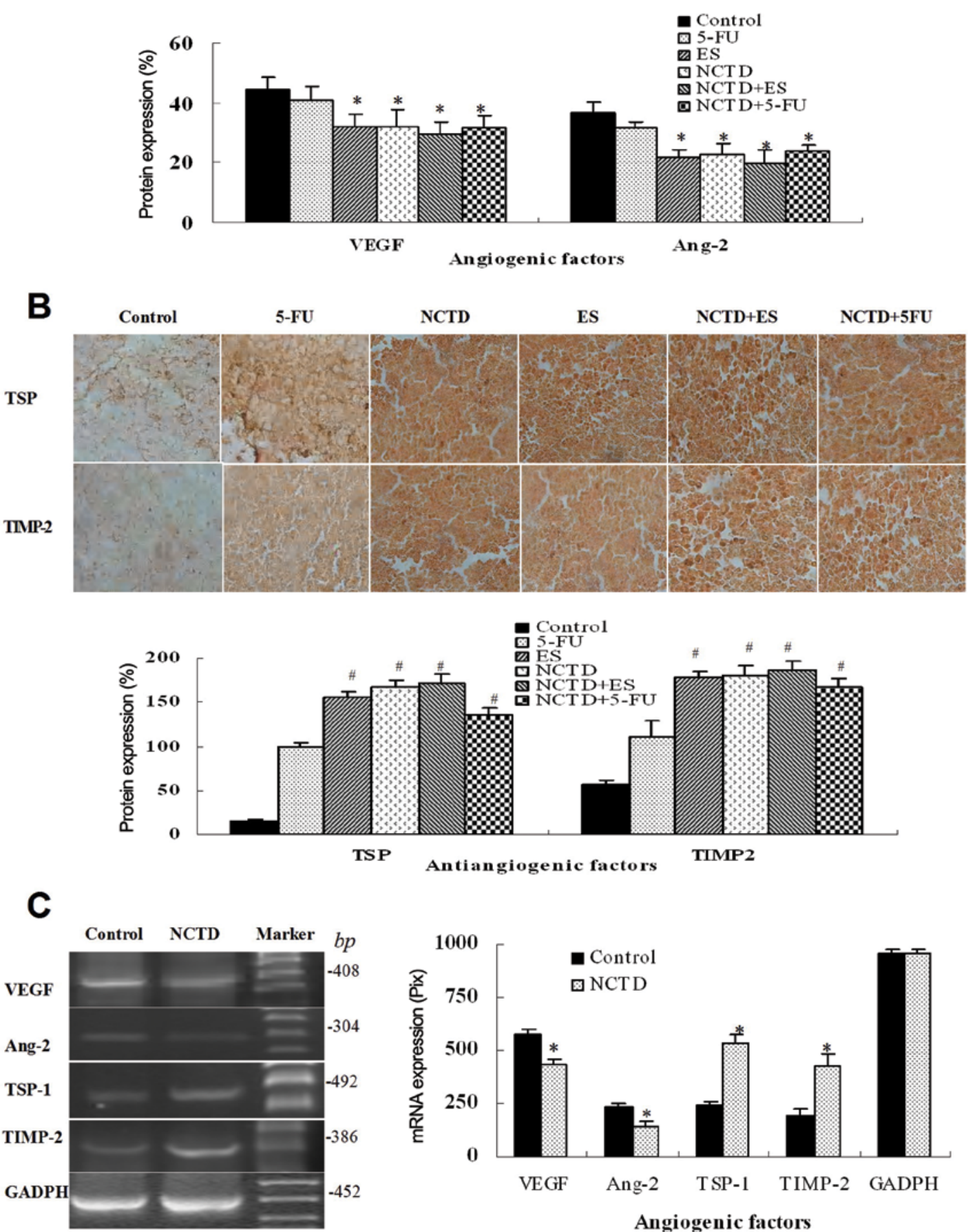

Angiogenic factors

Figure 9. NCTD affects the protein/mRNA expression of angiogenic and antiangiogenic factors in the xenograft tumor cells in vivo. (A and B) The protein expression of VEGF, Ang-2, TSP and TIMP-2 (SABC immunohistochemistry, magnification x200): the decreased expression of VEGF or Ang-2 protein (all "P<0.05) and the increased expression of TSP or TIMP-2 protein (all " $\mathrm{P}<0.01$ ) in NCTD group than in control and 5-FU groups; however, not significantly different from those of the ES, NCTD+5-FU and NCTD+ES groups. (C) The mRNA expression (Pix of the specific cDNA fragments bp) of VEGF, Ang-2, TSP-1 and TIMP-2 (RT-PCR): the mRNA expression of VEGF and Ang-2 were significantly down-regulated, with significant up-regulated TSP-1 or TIMP-2 mRNA expression in the NCTD group in comparison with the control group (all " $\mathrm{P}<0.05$ ). No difference on the expression of GADPH mRNA was observed between the control group and NCTD group. 
combine antiangiogenic drugs with traditional chemotherapies, or seek multifunctional medicines/therapies that simultaneously have antiangiogenic and antitumor activities (15,16,26-29).

Because of worse treatment results with surgical resection and chemoradiotherapy, and poor prognosis in the patients with gallbladder carcinoma (30,31,36-39), and because of high aggressiveness and predictable angiogenesis of gallbladder carcinomas (58-60), it is valuable to develop more effective comprehensive therapies such as combining antiangiogenic drugs with conventional chemotherapies, or traditional Chinese medicines which have multifunctional antitumor activities. NCTD is a demethylated form and low-cytotoxic derivative of cantharidin with anti-tumor properties, which is an active ingredient of the traditional Chinese medicine Mylabris, also is synthesized from furan and maleic anhydride via the DielsAlder reaction (40-42). It has been reported that NCTD inhibits the proliferation and growth of a variety of human tumor cells and is used in clinic to treat human cancers, e.g., hepatic, gastric, colorectal and ovarian carcinoma (43-46). We have reported that NCTD has multiple antitumor activities against gallbladder carcinomas in vitro and in vivo $(46,47)$. In this study, we have shown the antiangiogenic effect of NCTD for gallbladder cancers by the inhibitory experiments of NCTD for HUVECs in vitro, chicken embryo CAM in vivo and xenografted angiogenesis of gallbladder cancers in nude mice in vivo. Vascular endothelial cells such as HUVECs are the common target cells used in vitro to study the antiangiogenic activity of angiogenic inhibitors. The chicken embryo CAM is commonly used in vivo to study both angiogenesis and antiangiogenesis $(49,50,61)$. The xenograft model of human gallbladder carcinoma GBC-SD cells in nude mice has confirmed to be a good animal modal in vivo to study the antitumor activity of NCTD (47). Experimental results have shown that NCTD inhibited markedly the proliferation, growth, migration, invasion and capillary-like tube formation of HUVECs in vitro, reduced effectively angiogenesis of chick CAM and directly destroy the formed capillary vessels of chick CAM in vivo, in a dose- and time-dependent manner. In the experiment of xenografted tumors in nude mice, NCTD inhibited growth of the xenografted tumors, induced apoptosis of the xenografted tumor cells, prolonged survival time of the xenograft mice, and NCTD, similarly to ES, significantly decreased the xenograft MVD and vascular perfusion, inhibited and destroyed microvessels and angiogenesis of the xenografted tumors in vivo. Thus, we concluded that NCTD may be a potential antiangiogenic agent for gallbladder cancers.

Some studies showed that NCTD inhibited tumor progression through the cell cycle and interrupting DNA synthesis or upregulating of CD95 receptor and CD95 ligand on the cell surface (62). It has been reported that NCTD induced a P53-dependent apoptosis (63), mediated a Fas-dependent apoptotic cell death in human colorectal carcinoma cells (62), triggered the mitotic phase in human hepatoma cells (64), inhibited protein phosphatases $1,2 \mathrm{~A}$ and $2 \mathrm{~B}(65,66)$, and triggered apoptotic process by caspase-9, ERK, JNK, AP-1 and NF- $\kappa \beta$ signal pathways in human hepatoma HepG2 cells (67). It was reported that NCTD has angiogenic effect on colorectal carcinoma CT26 cells in implanted mice (67). In this study, we have shown the antiangiogenic effect of NCTD for gallbladder carcinomas.

Angiogenic factors and antiangiogenic factors of normal angiogenesis maintain comparatively their balanceable condi- tion. If the angiogenic cytokines were up-regulated, or the antiangiogenic cytokines were inhibited and decreased, tumor angiogenesis would took place (53). Thus, these angiogenic or antiangiogenic cytokines are a set of key-points and targets for antiangiogenic therapy for tumors. VEGF and Ang-2 are typical angiogenic factors. As the strongest incurring angiogenic cytokine, VEGF can specially stimulate vessel endothelium cell proliferation and angiogenesis $(4,5)$. VEGF is expressed highly in gallbladder carcinoma, incurs in neo-vessel coming up in the tumorigenesis procedure and positively correlates with MVD and tumor malignancy degree (69). Applying antibodies of VEGF and soluble receptors to inhibit VEGF can decrease vessel formation, tumor growth and metastasis. Bevacizumab (Avastin, a VEGF inhibitor) has been reported to exhibit antiangiogenic activities in clinical use $(17,18,26)$. As one of the angiopoietin families, Ang-2 involves the whole angiogenic procedure including early motility phase and inactive phase, further separates endothelium cells with vessel peripheral cells, and together with VEGF incurs vessels and growth (6,7). TSP and TIMP-2 are important antiangiogenic factors. TSP as one of the endo-angiogenic negative-regulating cytokines in inhibiting angiogenesis, which is very important for tumor growth and metastasis. The mechanism of TSP in anti-vessel forming and anti-tumor activity is connected with $\mathrm{CD}_{36}$, which inhibits endothelium cell moving and induce endothelium cell apoptosis $(8,9)$. As one of tissue inhibitors of metalloproteinase, TIMP-2 can obviously inhibit angiogenesis. It not only controls ECM decomposition, inhibits endothelium movement, affects activity and releasing of grow th factors from the ECM, but also inhibits vessel endothelium cells directly, down-regulates the expression of MMP-9 and VEGF, further leading to inhibition of angiogenesis $(10,11)$. It was reported that ES, an effective angiogenic inhibitor, could specially inhibit vessel endothelium cell proliferation, movement and vessels coming up, inducing apoptosis, further inhibiting angiogenesis and tumor growth $(20,56,57)$. In this study, NCTD, similarly to ES, significantly decreased the expression of VEGF and Ang-2 proteins/mRNAs and increased the expression of TSP and TIMP-2 proteins/mRNAs in the xenografted tumors of gallbladder carcinoma. Our results also indicated that MVD of the xenografted tumors was positively correlated with tumor volume, PCNA/apoptosis rate, expression of VEGF and Ang-2, but negatively correlated with the protein expression of TSP and TIMP-2. Thus, we confirmed that the NCTD antiangiogenic mechanisms maybe related with inhibiting and/or destroying angiogenesis, inducing apoptosis of vascular endothelial cells, down-regulating expression of the angiogenic factors such as VEGF, Ang-2, and up-regulated the expression of the antiangiogenic factors such as TSP, TMP-2.

In conclusion, NCTD is a potential antiangiogenic agent for gallbladder cancers, its antiangiogenic mechanisms may correlate with inhibition of angiogenesis, inducing vascular endothelial cell apoptosis, and affecting expression of angiogenic factors VEGF, Ang-2, TSP and TMP-2.

\section{References}

1. Folkman J: Anti-angiogenesis: new concept for therapy of solid tumor. Ann Surg 175: 409-416, 1972.

2. Folkman J: Angiogenesis in cancer, vascular, rheumatoid and other disease. Nat Med 1: 27-31, 1995. 
3. Huang $\mathrm{G}$ and Chen L: Tumor vasculature and microenvironment normalization: a possible mechanism of antiangiogenesis therapy. Cancer Biother Radiopharm 23: 661-667, 2008.

4. Grothey A and Ellis LM: Targeting angiogenesis driven by vascular endothelial growth factors using antibody-based therapies. Cancer J 14: 170-177, 2008.

5. O'Reilly MS: Antiangiogenesis and vascular endothelial growth factor/vascular endothelial growth factor receptor targeting as part of a combined-modality approach to the treatment of cancer. Int $\mathbf{J}$ Radiat Oncol Biol Phys 69: S64-S66, 2007.

6. Yoshiji H, Kuriyama S, Noguchi R, Yoshii J, Ikenaka Y, Yanase K, Namisaki T, Kitade M, Uemura M, Masaki T and Fukui H: Angiopoietin 2 displays a vascular endothelial growth factor dependent synergistic effect in hepatocellular carcinoma development in mice. Gut 54: 1768-1775, 2005.

7. Cao Y, Sonveaux P, Liu S, Zhao Y, Mi J, Clary BM, Li CY, Kontos CD and Dewhirst MW: Systemic overexpression of angiopoietin-2 promotes tumor microvessel regression and inhibits angiogenesis and tumor growth. Cancer Res 67: 3835-3844, 2007.

8. De Fraipont F, Nicholson AC, Feige JJ and van Meir EG: Thrombospondins and tumor angiogenesis. Trends Mol Med 7: 401-407, 2001

9. Kazerounian S, Yee KO and Lawler J: Thrombospondins in cancer. Cell Mol Life Sci 65: 700-712, 2008.

10. HajitouA, Sounni NE, Devy L, Grignet-Debrus C,Lewalle JM,LiH, Deroanne CF, Lu H, Colige A, Nusgens BV, Frankenne F, Maron A Yeh P, Perricaudet M, Chang Y, Soria C, Calberg-Bacq CM, Foidart JM and Noël A: Down-regulation of vascular endothelial growth factor by tissue inhibitor of metalloproteinase-2: effect on in vivo mammary tumor growth and angiogenesis. Cancer Res 61 3450-3457, 2001.

11. Zheng H, Takahashi H, Murai Y, Cui Z, Nomoto K, Niwa H, Tsuneyama K and Takano Y: Expressions of MMP-2, MMP-9 and VEGF are closely linked to growth, invasion, metastasis and angiogenesis of gastric carcinoma. Anticancer Res 26: 3579-3583, 2006.

12. Deplanque G and Harris AL: Anti-angiogenic agents: clinical trial design and therapies in development. Eur J Cancer 36: 1713-1724, 2000 .

13. Rhee $\mathrm{J}$ and Hoff PM: Angiogenesis inhibitors in the treatment of cancer. Expert Opin Pharmacother 6: 1701-1711, 2005.

14. Sato M, Arap W and Pasqualini R: Molecular targets on blood vessels for cancer therapies in clinical trials. Oncology (Williston Park) 21: 1346-1352, 2007

15. Tian F, Zhang XW, Tong YG, Yi YH, Zhang SL, Li L, Sun P, Lin LP and Ding J: PE, a new sulfated saponin from sea cucumber exhibits anti-angiogenic and anti-tumor activities in vitro and in vivo. Cancer Biol Ther 4: 874-882, 2005.

16. Zhou YX and Huang YL: Antiangiogenic effect of celastrol on the growth of human glioma: an in vitro and in vivo study. Chin Med J (Engl) 122: 1666-1673, 2009

17. Jenab-Wolcott $\mathbf{J}$ and Giantonio BJ: Bevacizumab: current indications and future development for management of solid tumors. Expert Opin Biol Ther 9: 507-517, 2009.

18. Sirohi B and Smith K: Bevacizumab in the treatment of breast cancer. Expert Rev Anticancer Ther 8: 1559-1568, 2008.

19. $\mathrm{Hu} \mathrm{B}$ and Cheng SY: Angiopoietin-2: development of inhibitors for cancer therapy. Curr Oncol Rep 11: 111-166, 2009.

20. Folkman J: Antiangiogenesis in cancer therapy-endostatin and its mechanisms of action. Exp Cell Res 312: 594-607, 2006.

21. Lawler J: Thrombospondin-1 as an endogenous inhibitor of angiogenesis and tumor growth. J Cell Mol Med 6: 1-12, 2002.

22. Grothey A and Galanis E: Targeting angiogenesis: progress with anti-VEGF treatment with large molecules. Nat Rev Clin Oncol 6: 507-518, 2009.

23. Gille J: Antiangiogenic cancer therapies get their act together: current developments and future prospects of growth factor- and growth factor receptor-targeted approaches. Exp Dermatol 15: $175-186,2006$

24. Chen HX and Cleck JN: Adverse effects of anticancer agents that target the VEGF pathway. Nat Rev Clin Oncol 6: 465-477, 2009

25. Higa GM and Abraham J: Biological mechanisms of bevacizumab-associated adverse events. Expert Rev Anticancer Ther 9: 999-1007, 2009

26. Ma J and Waxman DJ: Combination of antiangiogenesis with chemotherapy for more effective cancer treatment. Mol Cancer Ther 7: 3670-3684, 2008.

27. Blagosklonny MV: How Avastin potentiates chemotherapeutic drugs: action and reaction in antiangiogenic therapy. Cancer Biol Ther 4: 1307-1310, 2005,
28. Moniz M, Yeatermeyer J and Wu TC: Control of cancers by combining antiangiogenesis and cancer immunotherapy. Drugs Today (Barc) 41: 471-494, 2005

29. Kamrava M, Bernstein MB, Camphausen K and Hodge JW: Combining radiation, immunotherapy, and antiangiogenesis agents in the management of cancer: the Three Musketeers or just another quixotic combination? Mol Biosyst 5: 1262-1270, 2009.

30. Reddy SK and Clary BM: Surgical management of gallbladder cancer. Surg Oncol Clin North Am 18: 307-324, 2009.

31. Lazcano-Ponce EC, Miquel JF, Muñoz N, Herrero R, Ferrecio C, Wistuba II, Alonso de Ruiz P, Aristi Urista G and Nervi F: Epidemiology and molecular pathology of gallbladder cancer. CA Cancer J Clin 51: 349-364, 2001.

32. Li LD, Zhang SW, Lu FZ, Mu R, Sun XD and Huangpu XM: Research on characteristics of mortality spectrum and type composition of malignant tumors in China. Zhonghua Zhongliu Zazhi 19: 323-328, 1997.

33. Wang BS, Qin J, Deng J, Zhang BH, Han TQ and Shen MC: A survey on the diagnosis and treatment of biliary tract cancers in Shanghai. Zhonghua Waike Zazhi 43: 455-459, 2005.

34. Chakravarty KD, Yeh CN, Jan YY and Chen MF: Factors influencing long-term survival in patients with T3 gallbladder adenocarcinoma. Digestion 79: 151-157, 2009.

35. Konstantinidis IT, Deshpande V, Genevay M, Berger D, Fernandez-del Castillo C, Tanabe KK, Zheng H, Lauwers GY and Ferrone CR: Trends in presentation and survival for gallbladder cancer during a period of more than 4 decades: a single-institution experience. Arch Surg 144: 441-447, 2009.

36. Ishii H, Furuse J, Yonemoto N, Nagase M, Yoshino M and Sato T: Chemotherapy in the treatment of advanced gallbladder cancer. Oncology 66: 138-142, 2004.

37. Morise Z, Sugioka A, Tanahashi Y, Okabe Y, Ikeda M, Kagawa T and Takeura C: Treatment of patients with unresectable advanced carcinoma of biliary tract chemotherapy and surgical resection. Anticancer Res 29: 1783-1786, 2009.

38. Mahantshetty UM, Palled SR, Engineer R, Homkar G, Shrivastava SK and Shukla PJ: Adjuvant radiation therapy in gallbladder cancers: 10 years experience at Tata Memorial Hospital. J Cancer Res Ther 2: 52-56, 2006

39. Mojica P, Smith D and Ellenhorn J: Adjuvant radiation therapy is associated with improved survival for gallbladder carcinoma with regional metastatic disease. J Surg Oncol 96: 8-13, 2007.

40. Wang GS: Medical uses of Mylabris in ancient China and recent studies. J Ethnopharmacol 26: 147-162, 1989.

41. Liu J, Gao J and Liu X: Advances in the study of Cantharidin and its derivatives. Zhong Yao Cai 26: 453-455, 2003.

42. Ho YP, To KK, Au-Yeung SC, Wang X, Lin G and Han X: Potential new antitumor agents from an innovative combination of demethylcantharidin, a modified traditional Chinese medicine with a platinum moiety. J Med Chem 44: 2065-2068, 2001.

43. Yang EB, Tang WY, Zhang K, Cheng LY and Mack PO: Norcantharidin inhibits growth of human HepG2 cell-transplanted tumor in nude mice and prolongs host survival. Cancer Lett 117: 93-98, 1997.

44. Yi SN, Wass J, Vincent $\mathrm{P}$ and Iland H: Inhibitory effect of norcantharidin on K562 human myeloid leukemia cells in vitro. Leuk Res 15: 883-886, 1991.

45. An WW, Wang MW, Tashiro S, Onodera S and Ikejima T: Norcantharidin induces human melanoma A375-S2 cell apoptosis through mitochondrial and caspase pathways. J Korean Med Sci 19: 560-566, 2004

46. Fan YZ, Fu JY, Zhao ZM and Chen CQ: Inhibitory effect of norcantharidin on the growth of human gallbladder carcinoma GBC-SD cells in vitro. Hepatobiliary Pancreat Dis Int 6: 72-80, 2007.

47. Fan YZ, Zhao ZM, Fu JY, Chen CQ and Sun W: Norcantharidin inhibits growth of human gallbladder carcinoma xenografted tumors in nude mice by inducing apoptosis and blocking the cell cycle in vivo. Hepatobiliary Pancreat Dis Int 9: 414-422, 2010.

48. Kubota Y, Kleinman HK, Martin GR and Lawley TJ: Role of laminin and basement membrane in the morphological differentiation of human endothelial cells into capillary-like structures. J Cell Biol 107: 1589-1598, 1988.

49. Ribatti D, Nico B, Vacca A, Roncali L, Burri PH and Djonov V: Chorioallantoic membrane capillary bed: a useful target for studying angiogenesis and anti-angiogenesis in vivo. Anat Rec 264: 317-324, 2001 .

50. Ribatti D: The chick embryo chorioallantoic membrane in the study of tumor angiogenesis. Rom J Morphol Embryol 49 : $131-135,2008$. 
51. Weinder N: Current pathologic methods for measuring intratumoral microvessel density within breast carcinoma and other solid tumors. Breast Cancer Res Treat 36: 169-180, 1995.

52. Sun W, Fan YZ, Zhang W and Ge CY: A pilot histomorphology and hemodynamic of vasculogenic mimicry in gallbladder carcinomas in vivo and in vitro. J Exp Clin Cancer Res 30: 46, 2011.

53. Liotta LA, Steeg PS and Stetler-Stevenson WG: Cancer metastasis and angiogenesis: an imbalance of positive and negative regulation. Cell 64: 327-336, 1991.

54. Folkman J: Seminars in Medicine of the Beth Israel Hospital, Boston. Clinical applications of research on angiogenesis. N Engl J Med 333: 1757-1763, 1995.

55. Thompson WD, Li WW and Maragoudakis M: The clinical manipulation of angiogenesis: pathology, side effects, surprises, and opportunities with novel human therapies. J Pathol 190: 330-337, 2000

56. O'Reilly MS, Boehm T, Shing Y, Fukai N, Vasios G, Lane WS, Flynn E, Birkhead JR, Olsen BR and Folkman J: Endostatin: an endogenous inhibitor of angiogenesis and tumor growth. Cell 88: 277-285, 1997.

57. Shi W, Teschendorf C, Muzyczka N and Siemann DW: Adenoassociated virus-mediated gene transfer of endostatin inhibits angiogenesis and tumor growth in vivo. Cancer Gene Ther 9 : 513-521, 2002.

58. Giatromanolaki A, Sivridis E, Koukourakis MI, Polychronidis A and Simopoulos C: Prognostic role of angiogenesis in operable carcinoma of the gallbladder. Am J Clin Oncol 5: 38-41, 2002.

59. Legan M, Luzar B, Ferlan-Marolt V and Cör A: Cyclooxygenase-2 expression determines neo-angiogenesis in gallbladder carcinomas. Bosn J Basic Med Sci 6: 58-63, 2006.

60. Giatromanolaki A, Sivridis E, Simopoulos C, Polychronidis A, Gatter KC, Harris AL and Koukourakis MI: Hypoxia inducible factors 1alpha and 2alpha are associated with VEGF expression and angiogenesis in gallbladder carcinomas. J Surg Oncol 94: 242-247, 2006.

61. Seidlitz E, Korbie D, Marien L, Richardson M and Singh G: Quantification of anti-angiogenesis using the capillaries of the chick chorioallantoic membrane demonstrates that the effect of human angiostatin is age-dependent. Microvasc Res 67: 105-116, 2004.
62. Peng F, Wei YQ, Tian L, Yang L, Zhao X, Lu Y, Mao YQ, Kan B, Lei S, Wang GS, Jiang Y, Wang QR, Luo F, Zou LQ and Liu JY: Induction of apoptosis by norcantharidin in human colorectal carcinoma cell lines: involvement of the CD95 receptor/ligand. J Cancer Res Clin Oncol 128: 223-230, 2002.

63. Hong CY, Huang SC, Lin SK, Lee JJ, Chueh LL and Lee CH: Norcantharidin-induced post-G(2)/M apoptosis is dependent on wild-type p53 gene. Biochem Biophys Res Commun 276: 278-285, 2000

64. Chen YN, Chen JC, Yin SC, Wang GS, Tsauer W, Hsu SF and Hsu SL: Effector mechanisms of norcantharidin-induced mitotic arrest and apoptosis in human hepatoma cells. Int J Cancer 100: $158-165,2002$.

65. McCluskey A, Walkom C, Bowyer MC, Ackland SP, Gardiner E and Sakoff JA: Cantharimides: a new class of modified cantharidin analogues inhibiting protein phosphatases 1 and 2A. Bioorg Med Chem Lett 11: 2941-2946, 2001.

66. Baba Y, Hirukawa N and Sodeoka M: Optically active cantharidin analogues possessing selective inhibitory activity on Ser/Thr protein phosphatase $2 \mathrm{~B}$ (calcineurin): implications for the binding mode. Bioorg Med Chem 13: 5164-5170, 2005.

67. Chen YN, Cheng CC, Chen JC, Tsauer W and Hsu SL: Norcantharidin-induced apoptosis is via the extracellular signalregulated kinase and c-Jun-NH2- terminal kinase signaling pathways in human hepatoma HepG2 cells. Br J Pharmacol 140: 461-470, 2003.

68. Chen YJ, Tsai YM, Kuo CD, Ku KL, Shie HS and Liao HF: Norcantharidin is a small-molecule synthetic compound with anti-angiogenesis effect. Life Sci 85: 642-651, 2009.

69. Giatromanolaki A, Koukourakis MI, Simopoulos C, Polychronidis A and Sivridis E: Vascular endothelial growth factor (VEGF) expression in operable gallbladder carcinomas. Eur J Surg Oncol 29: 879-883, 2003. 